\title{
The Term Structure of Lease Rates with Endogenous Default Triggers and Tenant Capital Structure: Theory and Evidence
}

\author{
Sumit Agarwal, Brent W. Ambrose, Hongming Huang, and \\ Yildiray Yildirim*
}

\begin{abstract}
This paper focuses on the defaultable lease rate term structure with endogenous default. We combine the competitive lease market argument proposed by Grenadier (1996) and the endogenous default structural model proposed by Leland and Toft (1996) to examine the interaction between the lessee's capital structure and the equilibrium lease rate. Under this framework, determining the lease rate is a simultaneous equation problem that captures the trade-off between debt and lease financing. Using data on 2,482 real estate lease transactions, we empirically confirm the predictions derived from the numerical analysis of the model.
\end{abstract}

\section{Introduction}

In December 2005, Lehman Brothers investment bank signed a lease for 160,000 square feet of office space at 1301 Avenue of the Americas in New York, becoming the largest tenant in the building, with over 500,000 square feet under its control. ${ }^{1}$ At the time, Lehman Brothers was one of the most profitable investment banks and a major user of commercial office space in New York. Less than 3 years later, the September 2008 Lehman Brothers bankruptcy filing and the resulting uncertainty regarding its lease at 1301 Avenue of the Americas reinforces the notion that tenant credit risk is an integral component to understanding the term structure of lease rates on commercial property.

*Agarwal, ushakri@yahoo.com, Economic Research, Federal Reserve Bank of Chicago, 230 S. LaSalle St., Chicago, IL 60604; Ambrose, bwa10@psu.edu, Institute for Real Estate Studies, Pennsylvania State University, University Park, PA 16802; Huang, hongming@ncu.edu.tw, Department of Finance, National Central University, No. 300, Jung-da Rd., Jung-Li, Taiwan 320, R.O.C.; and Yildirim, yildiray@syr.edu, Whitman School of Management, Syracuse University, 721 University Ave., Ste. 500, Syracuse, NY 13244. We thank Itzhak Ben-David, Hendrik Bessembinder (the editor), Steven Grenadier (the referee), and Raymond Kan for their helpful comments and suggestions. The views expressed in this research are those of the authors and not necessarily those of the Federal Reserve System or the Federal Reserve Bank of Chicago.

${ }^{1}$ See Geiger (Dec. 28, 2005). 
The connection between tenant credit risk and lease rates is not new. For example, in a study of the ex post performance of leases, Lease, McConnell, and Schallheim (1990) found significant credit risk in typical lease contracts. The leases in their sample experienced a default rate of approximately $20 \%$ and a recovery rate of $38 \%$ relative to the original cost of the asset, or $64 \%$ relative to the present value of the remaining lease payments plus estimated salvage value. Thus, their analysis suggests that lease valuations must incorporate tenant credit risk just as corporate bond values reflect default risk. Building on this finding, a number a studies have proposed models that attempt to incorporate tenant credit risk into the determination of lease rates. ${ }^{2}$ However, these lease valuation models rely on exogenous default triggering mechanisms, and thus, do not account for the substitution of lease financing and debt financing.

In his seminal text on corporate leasing, Schallheim (1994) succinctly outlines the economic principles showing that leasing is simply a substitute for debt financing. In the context of an efficient market, the substitutability of debt and lease financing implies that the tenant's capital structure must impact the term structure of lease rates. More recently, Yan (2006) presents evidence confirming the substitutability of debt and leases using information on capitalized leases for large firms.

In this paper, we propose and empirically test an endogenous structural model of the term structure of lease rates that is simultaneously determined by the lessee firm's capital structure and the competitive lease market. Compared with other exogenous defaultable lease contract valuations, this setting is more realistic and can effectively link the lessee's financial decisions with current conditions in the leasing market.

To preview our results, we show that the term structure of lease rates is integral to the lessee's capital structure. The numerical example shows that lessee debt (capital structure) has a direct impact on the equilibrium lease rate. However, the impact arises from multiple sources of interaction resulting from the endogenous default boundary that is a function of both the use of debt and leasing. Finally, our model also provides an opportunity to examine the impact of changes in government tax policies with respect to depreciation. For example, we show the relative sensitivity of lease rates to changes in the marginal tax rates facing both the lessor and lessee.

The remainder of the paper is organized as follows. Section II summarizes the existing literature on lease valuation. Section III then describes the no-arbitrage setting for determining lease rates and provides the defaultable fair lease rate under a competitive lease market. In Section IV we propose a structural model based on the model first developed by Leland and Toft (1996) to express the components of firm value given that the firm uses debt and lease contracts as its financing instruments. Section V presents the endogenous decision rule to derive the optimal bankruptcy trigger level, and Section VI provides comparative statics and numerical examples to show the impact of relevant parameters on the term structure of

\footnotetext{
${ }^{2}$ For example, see Grenadier (1996) for an example of an exogenous structural credit risk model for fairly pricing lease contracts, and Lewis and Schallheim (1992) for a single-period model that incorporates the tenant's capital structure and credit risk.
} 
lease rates. The numerical analysis continues in Section VII with a discussion of the impact of tax rates and tax policy on the lease term structure. In Section VIII, we present an empirical analysis using real estate lease transactions to validate the predictions derived from the numerical analysis. We conclude in Section IX.

\section{Literature Review}

The determination of lease rates is widely discussed in the financial literature. In one of the first studies of corporate leasing, Miller and Upton (1976) propose an equilibrium structure for determining the lease versus buy policy of a firm and the determination of lease rates. Following their work, Schallheim and McConnell (1985) and McConnell and Schallheim (1983) established a noarbitrage framework to price leases and insurance premiums of leased assets in discrete-time cases. Later, Grenadier (1995) was the first to apply a continuoustime model and competitive market rationale to derive the term structure of lease rates. In Grenadier's model, lease rates are endogenously determined, and driven by the trade-off decision between construction cost and developer's profit. Hence, the lease market equilibrium is determined by a firm's decision given a competitive market assumption. However, credit risk is not considered.

More recently, a number of studies have extended the lease valuation models to incorporate more realistic assumptions regarding the nature of the competitive leasing market. For example, Grenadier (2005) uses the same equilibrium approach as Grenadier (1995) but changes the competitive market assumption into a monopolistic assumption by using a game-theoretic-based approach. In this paper, Grenadier suggests that the shape of the term structure is determined by 2 factors. First, the term structure is a function of the expectations of future short-term lease rates, similar to the expectation hypothesis in interest rate term structure models. Second, the term structure of lease rates depends upon the number of competitors in the leasing market. Stanton and Wallace (2009) apply the no-arbitrage framework and continuous-time modeling into the determination of lease rates as well and provide an empirical study of the term structure of commercial lease rates. $^{3}$ In addition, Clapham and Gunnelin (2003) apply the concept of interest rate swaps to determine lease rates. In their model, the spot interest rate and lease service flow follow continuous-time stochastic processes. Moreover, they regard the lessee paying a fixed lease rent as the fixed interest rate payer in a swap contract, and the lessor who promises to provide stochastic service flow as the float interest payer in a swap contract. From this perspective, they use a forward measure derived from pricing option contracts under stochastic interest rates to simplify the expression of the property service flows. They suggest that the expectation hypothesis of lease rates is significantly affected by risk aversion and interest rate uncertainty, which complements the proposition made by Grenadier (1995). Clapham and Gunnelin also propose a basic reduced-form model for determining lease rates under credit risk. However, this model is not fully developed.

\footnotetext{
${ }^{3}$ Ambrose, Hendershott, and Kłosek (2002) use the no-arbitrage framework to derive a closedform solution to a lease with adjusting rents.
} 
Grenadier (1996) incorporates default risk into lease rate determination also by using a competitive market rationale. In this article, the default process is modeled on the first passage time that the lessee firm's asset value hits a given bankruptcy level, which is the so called "structural model" in the broader credit risk literature. In Grenadier's (1996) analysis, the lease rate credit spread, which is defined as the difference between the lease rate and the risk-free rate, is influenced by the lease duration, default recovery rate, correlation between leased assets and the lessee firm's assets, etc. However, only the exogenous default level is considered. From this standpoint, the lessee firm's capital structure decision is not relevant in determining lease rates. In addition, the lessee firm's likelihood to default is not endogenously related to how much it pays for its lease service.

In contrast, we assume that the firm's capital structure is taken into consideration when determining the lease rate. Our model is closely related to that of Lewis and Schallheim (1992), who also consider the lessee firm's capital structure decision and credit risk in determining lease rates. However, their model assumes a simplified single-period framework that overweighs the lease payment in the capital structure decision process. Due to the limitation of their single-period model, the default decision can only be made based on the claim priority in a period, instead of an endogenous default decision, which considers all related cash flows in the future. Similarly, the model developed in Grenadier (1996) is based on an exogenous default triggering level where the lease does not affect the firm's default probability, and thus, does not account for the firm's capital structure. However, the amount of lease financing and the lease rent for leased assets are always a concern in a firm's financial decision making and can not be isolated out of modeling. This is the main issue we address.

One of the major differences between the earlier exogenous default models and our endogenous default model is that the exogenous models do not depend on an equity-maximizing decision. Rather, default is triggered by the 0 net worth condition, such as when the collateral asset value (or cash flow) falls to a certain exogenously given barrier. However, endogenous default is similar to an optimal decision that depends on equity maximization. In this model, the endogenous default barrier depends on the model parameters, such as the risk-free rate, lease maturity, interest rate volatility, and others. In contrast, an exogenous default barrier is not affected by any of these model parameters.

\section{Determination of Lease Rates}

We begin by applying the spirit of Brennan and Kraus (1982), McConnell and Schallheim (1983), and Stanton and Wallace (2009) and use the no-arbitrage argument to determine the operating lease rates. For simplicity, we consider the lease contract without any embedded options. ${ }^{4}$ The underlying asset value

\footnotetext{
${ }^{4}$ Schallheim and McConnell (1985), Stanton and Wallace (2009), and Grenadier (1995), (1996) incorporate many embedded options in lease contracts to discuss the fair leasing rate. Here we only focus on the interaction between lease rate dynamics and capital structure; therefore, we ignore those options in lease contracts to purify our discussion.
} 
is determined by the present value of its future service flows, ${ }^{5}$ and is given by

$$
\frac{d S_{\mathrm{BD}}}{S_{\mathrm{BD}}}=\mu_{s} d t+\sigma_{s} d W_{S}
$$

where $S_{\mathrm{BD}}$ is the service flow before depreciation, $\mu_{s}$ is the drift rate of the service flow process, $\sigma_{s}$ is the volatility of this process, and $d W_{S}$ is the standard Brownian motion under physical measure $\mathbf{P}$. On the other hand, if we consider the depreciation of the leased asset that is reflected in the drift rate of the service flow process with payout rate $q$, we can write the service flow process after depreciation, $S_{\mathrm{AD}}$, as

$$
\frac{d S_{\mathrm{AD}}}{S_{\mathrm{AD}}}=\left(\mu_{s}-q\right) d t+\sigma_{S} d W_{S}
$$

In equation (2), $q$ represents the property economic depreciation rate, not the accounting depreciation rate. Although the concept of accounting depreciation originally reflected actual economic depreciation, over time, the link between real economic depreciation and accounting depreciation that is set by the government tax policies has deviated. To see the effect of the difference between accounting and economic depreciation, we assume that accounting depreciation is scaled to a proportion $(\chi)$ of economic depreciation. If $\chi=1$, then accounting and economic depreciation are equivalent. If $\chi<1$, then government tax policy sets accounting depreciation rules such that the tax deduction associated with depreciation is less than the full economic depreciation. For example, if the building physically depreciates over 25 years and the government sets the depreciable life at 39.5 years, then $\chi=0.625 .{ }^{6}$ However, in the 1980s, government tax policy provided for accelerated depreciation, where the depreciable life was set to 15 years. A 15 -year depreciable life implies that $\chi=1.675$ under the assumption of a 25 -year physical life.

In the analysis below, we explore the implications on lease rates of altering the accounting depreciation rate. We also define the lease rate for a risk-free tenant and a risky tenant, assuming the lessor writes an operating lease contract of $t$ periods, and the leased asset provides continuous service flows following stochastic differential equations (1) and (2).

\section{A. Case 1: The Risk-Free Lessee}

Assume the lessee is risk-free and the lessor's net cost of offering a lease contract is the present value of the service flows before depreciation minus the

\footnotetext{
${ }^{5}$ In an economic sense, we can regard the service flow process as the economic value process the leased asset provides over time.

${ }^{6}$ The typical life expectancy for major structural items, such as a building roof, is 20-25 years.
} 
tax-shield benefit associated with the depreciation expense. Thus, the lessor's net cost is defined as

$$
\begin{gathered}
\widetilde{\mathrm{E}}\left\{\int_{0}^{t} S_{\mathrm{BD}}(u) e^{-r u} d u-\chi \mathrm{TAX}_{c}\left[\left(\int_{0}^{t} S_{\mathrm{BD}}(u) e^{-r u} d u\right)\right.\right. \\
\left.\left.-\left(\int_{0}^{t} S_{\mathrm{AD}}(u) e^{-r u} d u\right)\right]\right\}
\end{gathered}
$$

where, $\int_{0}^{t} S_{\mathrm{BD}}(u) e^{-r u} d u$ represents the present value of the service flows before depreciation from time 0 to time $t$ discounted by the risk-free rate under riskneutral measure $\widetilde{P}$; similarly, $\int_{0}^{t} S_{\mathrm{AD}}(u) e^{-r u} d u$ represents the present value of the service flow after depreciation under the risk-neutral measure $\widetilde{P}$. Here, $\widetilde{\mathrm{E}}(\cdot)$ is the expectation under $\widetilde{P}$. The difference between these 2 terms is the depreciation cost of the leased asset from time 0 to $t$. $\mathrm{TAX}_{c}$ is the corporate tax rate applied to the lessor. As introduced above, $\chi$ is the depreciation adjustment factor that reconciles the government-mandated accounting depreciation to the actual physical depreciation.

The 1 st term in equation (3) is the expected present value of service flows before depreciation from time 0 to $t$, and the 2 nd term in equation (3) is the taxshield benefit provided by depreciation expense. The difference between these 2 terms is the net cost of providing the leased property from the lessor's perspective, recognizing the tax-shield benefit associated with the depreciation expense. ${ }^{7}$ In a competitive market, the net cost of the lease is exactly equal to the present value of the future lease payments $\left(\int_{0}^{t} r_{N}^{t} e^{-r u} d u\right)$ and equals $r_{N}^{t}\left(\left(1-e^{-r t}\right) / r\right)$, where $r_{N}^{t}$ denotes the nondefaultable operating lease rent with maturity $t$. Assuming the asset service flow follows the dynamics of equation (2), then the default risk-free lease rate is ${ }^{8}$

$$
\begin{aligned}
r_{N}^{t}= & S(0)\left(\frac{e^{\left(\mu_{s}-\delta \sigma_{S}-r-q\right) t}-1}{\mu_{s}-\delta \sigma_{s}-r-q}\right)\left[\left(1-\chi \mathrm{TAX}_{c}\right) Q+\chi \mathrm{TAX}_{c}\right] \\
& \times\left(\frac{r}{1-e^{-r t}}\right),
\end{aligned}
$$

where

$$
Q=\left(\frac{e^{\left(\mu_{S}-\delta \sigma_{S}-r\right) t}-1}{e^{\left(\mu_{S}-\delta \sigma_{S}-r-q\right) t}-1}\right)\left(\frac{\mu_{S}-\delta \sigma_{S}-r-q}{\mu_{S}-\delta \sigma_{S}-r}\right),
$$

$S(0)$ is the initial value of the service flow process, and $\delta$ is the market price of risk of the risk factor implicit in the service flow process. ${ }^{9}$ In this case, the lease rate does not consider the lessee's credit condition, and only reflects the lessee's corporate tax rate, the government's depreciation tax-shield policy, and the service flow dynamics of leased assets.

\footnotetext{
${ }^{7}$ This expression of operating lease net cost is the same as that provided in Smith and Wakeman (1985), which states that lease rent is equal to the cost of capital and depreciation cost of providing the lease minus the tax-deductible benefit of the lease.

${ }^{8}$ This proof can be done by applying the Fubini Theorem in stochastic calculus. For more about this theorem, please refer to Arnold (1974).

${ }^{9}$ The Appendix shows the derivation of equation (4).
} 


\section{B. Case 2: The Risky Lessee}

We now examine the lease contract for a risky tenant. In this case, the lessor adds a default risk premium to the lease rent to compensate for potential losses. If the lessee defaults and files for bankruptcy at $\tau(0<\tau<t)$, the lessee stops paying its debt claims until the bankruptcy is resolved. ${ }^{10}$ Meanwhile, under the petition of the court, the lessee can continue using the leased asset by continuing the lease payment. Therefore, a lease contract under default risk is similar to a defaultable corporate bond with default recovery, and the default recovery is part of the future lease payments.

Recall that the portfolio value of a default-free lease with maturity $t$ is $r_{N}^{t}((1-$ $\left.e^{-r t}\right) / r$ ). Similarly, the portfolio value of the default-risky case is the present value the lease rate $r_{R}^{t}$ from origination to default time $\tau$, and the recovery of remaining lease rentals from time $\tau$ to maturity time $t$. Under these conditions, we can express the value of the default-risky lease as

$$
\int_{0}^{t} e^{-r \tau} r_{R}^{t}\left(1-F\left(\tau ; V, V_{B}\right)\right) d \tau+\int_{0}^{t} e^{-r \tau} \rho_{R}^{t} R_{R}^{t-\tau} f\left(\tau ; V, V_{B}\right) d \tau,
$$

where $F\left(\tau ; V, V_{B}\right)$ is the cumulative default probability up to time $\tau$ under measure $\widetilde{P}$, and $f\left(\tau ; V, V_{B}\right)$ is the instantaneous default probability under measure $\widetilde{P}$ at time $\tau$. For simplicity, we assume the recovery rate $\rho_{R}^{t}$ is a constant. Here, $R_{R}^{t-\tau}$ is the present value of the remaining default-risky lease payments, and it can be expressed as $r_{R}^{t}\left(\left(1-e^{-r(t-\tau)}\right) / r\right)$. The 1 st term in expression (5) represents the expected discounted lease payment flows from 0 to $\tau$. The 2 nd term represents the expected discounted value of the remaining lease payments after default happens.

When the market is in equilibrium, the portfolio value in case 1 is equal to case 2. This argument is similar to the one in Grenadier (1996), where he argues that any 2 methods of selling the service flow of the asset for $t$ years must have the same value. The 1 st method is to sell the service flow to a credit risk-free tenant with a credit risk-free lease rate. Alternatively, one can sell the service flow to a credit risky tenant with a credit risky lease rate. The 1 st method provides a series of stationary lease incomes to the lessor for a fixed period. The 2 nd method provides a series of credit risk compensated lease incomes to the lessor for a uncertain period. Thus, following this logic, we combine equations (4) and (5) and express the defaultable lease rate with a maturity of $t$ as

$$
r_{R}^{t}=r_{N}^{t}\left[\frac{1-e^{-r t}}{\left(1-e^{-r t}\right)-\left(1-\rho_{R}^{t}\right)\left(G(t)-F(t) e^{-r t}\right)}\right],
$$

where the definitions of $F(t), G(t)$ are expressed in the Appendix. ${ }^{11}$ This expression also explains the relation between the risky lease rate and the risk-free lease rate. The denominator represents the discount factor associated with a defaultrisky lease, and the numerator is the discount factor associated with a risk-free

\footnotetext{
${ }^{10}$ See Barclay and Smith (1995) or Graham, Lemmon, and Schallheim (1998). For a practice perspective, see Rosen and Rooney (2002).

${ }^{11}$ The Appendix also contains the derivation of equation (6).
} 
lease. The 1st part of the denominator is the default-free discount factor, which is the same as the numerator. The 2 nd part is the loss rate, $\left(1-\rho_{R}^{t}\right)$, times the difference between the lessee's accumulated discounted default probability and discounted accumulated default probability; therefore, it is positive. From this equation, when the lessee's default probability increases, implying $(G(t)-$ $\left.F(t) e^{-r t}\right)$ increases, the value of the denominator decreases. ${ }^{12}$ Hence, the risky lease rate increases to compensate for the increase in default probability. In addition, when the expected recovery rate increases, the lessor recovers more when the lessee defaults, and thus, the risky lease rate decreases, all else being equal.

Equation (6) provides an intuitive explanation of the relationship between the risky lease rate and the risk-free lease rate. Note that previous research assumes the lease rate is exogenous to the lessee's capital structure and is only determined by market competition. However, from equation (6), we observe that lease rates are affected by both lease market competition and the lessee's capital structure as reflected in its default probability. Therefore, the lease rate determination problem becomes a simultaneous equation problem and is conditional upon the firm's capital structure and the leasing market.

\section{The Capital Structure Setting}

As in Merton (1974), Black and Cox (1976), Brennan and Schwartz (1978), and Leland and Toft (1996), we consider a firm with productive assets whose unleveraged value $V$ follows a continuous diffusion process with constant proportional volatility $\sigma_{V}$ :

$$
\frac{d V}{V}=\left(\mu_{V}(t)-\delta_{V}\right) d t+\sigma_{V} d W_{V}
$$

where $\mu_{V}(t)$ denotes the total expected rate of return on asset value $V, \delta_{V}$ is the constant fraction of value paid out to all security holders, and $d W_{V}$ is the increment of a standard Brownian motion. The value $V$ includes the value of the net cash flows generated by a firm's productive activities.

In the following sections, we derive the firm's endogenous default boundary conditions assuming the firm uses debt and leases to finance its productive assets. In order to provide a tractable framework, we first consider the use of a lease conditional upon the firm's existing capital structure. We then examine the debt contract. Finally, we combine the firm's capital structure with the lease decision to determine the endogenous default boundary.

\section{A. Leasing}

Suppose a firm has an existing capital structure (comprising debt and equity) and wishes to acquire the use of an additional asset through lease financing. The firm writes an operating lease contract maturing at $t$ for this asset. Furthermore,

\footnotetext{
${ }^{12}\left(G(t)-F(t) e^{-r t}\right)=\int_{0}^{t} e^{-r \tau} f\left(\tau ; V, V_{B}\right) d \tau-\int_{0}^{t} e^{-r t} f\left(\tau ; V, V_{B}\right) d \tau=\int_{0}^{t}\left(e^{-r \tau}-e^{-r t}\right) f(\tau ;$ $\left.V, V_{B}\right) d \tau>0$.
} 
assume the firm's value process continues without a time limit unless $V$ falls to a default-triggering value $V_{B}$, defined below. If $V$ hits this default-triggering value, the firm defaults on its liabilities. Because of the nature of the lease contract, the lessor can recover part of the remaining lease payments even after default. From the lessor's perspective, the value of a lease contract is given by the expression (5), the fair value of the lease contract. By applying the integration by parts technique to expression (5), we obtain the lease contract value $l_{R}\left(V ; V_{B}, t\right)$ :

$$
\begin{aligned}
l_{R}\left(V ; V_{B}, t\right)= & r_{R}^{t}\left(\frac{1-e^{-r t}}{r}\right)-\frac{r_{R}^{t}}{r}\left(G(t)-e^{-r t} F(t)\right) \\
& +\rho_{R}^{t} \frac{r_{R}^{t}}{r}\left(G(t)-e^{-r t} F(t)\right) .
\end{aligned}
$$

The 1st term on the right-hand side (RHS) of expression (8) is the present value of future lease payments, the 2 nd term is the lease payment loss if the lessee defaults, and the 3rd term is the recovery of future lease payments conditional upon default. Previous studies have assumed that the bankruptcy boundary, $V_{B}$, is exogenous. However, Leland and Toft (1996) propose a condition to determine the bankruptcy boundary endogenously. Following their model, the default probability as well as all contingent claims on the firm's assets are affected by this endogenous bankruptcy boundary. Notice that $r_{R}^{t}$ in expression (8) is determined by expression (5), which is a function of $G(t)$ and $F(t)$. Therefore, $r_{R}^{t}$ is not a constant.

\section{B. Debt}

We assume for the sake of simplicity that the firm has a single debt issue with maturity $t$, coupon $c(t)$, and principal $p(t)$. Upon bankruptcy, the bondholder recovers a fraction $\rho_{D}(t)$ of the firm's net asset value of $\widetilde{V}_{B}$, where $\widetilde{V}_{B}$ represents the net asset value after bankruptcy cost and the present value of lessor's recovery lease payments at the time of default. In other words, $\rho_{D}(t)$ is the recovery rate for a debt with maturity $t$. Thus, we can write the value of risky debt as

$$
\begin{aligned}
d\left(V ; V_{B}, t\right)= & \int_{0}^{t} e^{-r \tau} c(t)\left(1-F\left(\tau ; V, V_{B}\right)\right) d \tau \\
& +p(t) e^{-r t}\left(1-F\left(\tau ; V, V_{B}\right)\right) \\
& +\int_{0}^{t} e^{-r \tau} \rho_{D}(t) \widetilde{V}_{B} f\left(\tau ; V, V_{B}\right) d \tau .
\end{aligned}
$$

If the firm does not declare bankruptcy, then the 1st term on the RHS of expression (9) represents the present value of coupon payments, and the 2 nd term represents the present value of the principal payment. The $3 \mathrm{rd}$ term represents the present value of the net asset value accruing to the debt holders if bankruptcy occurs. Thus, we can rewrite equation (9) as

$$
\begin{aligned}
d\left(V ; V_{B}, t\right)= & \frac{c(t)}{r}\left(1-e^{-r t}\right)-\frac{c(t)}{r}\left(G(t)-F(t) e^{-r t}\right) \\
& +e^{-r t} p(t)(1-F(t))+\int_{0}^{t} e^{-r \tau} \rho_{D}(t) \widetilde{V}_{B} f\left(\tau ; V, V_{B}\right) d \tau
\end{aligned}
$$




\section{Aggregated Values of Lease and Debt}

In order to simplify the analysis, we assume that the firm operates in an environment with stationary debt and lease structure. As a result, the firm continuously sells a constant amount of new debt with maturity $T_{D}$ from issuance that is redeemed at par if the firm is still solvent at $T_{D}$. New debt is issued with a principal amount of $p=P / T_{D}$ per year, where $P$ is the total principal amount of outstanding debt. As the same amount of old debt is retired per year, the firm's debt structure is stationary. As long as the firm remains solvent, the total outstanding principal amount at any time $s$ is $P$, and the firm has a uniform distribution over maturities in the interval $\left(s, T_{D}\right)$. The total coupon payment is $C$ per year, where debt with principal pays a constant coupon $c=C / T_{D}$ and the total annual debt service payment is $C+P / T_{D}$. Furthermore, we assume equal seniority of all outstanding debt, implying that the sum of all fractional claims $\rho_{D}(t)$ for debt of all maturities outstanding equals 1 , and $\rho_{D}(t)=1 / T_{D}$ per year for all $t$.

In addition, the firm continuously signs an operating lease contract with maturity $T_{L}$. Suppose that the total lease payment per year is $\Omega_{R}$. Following the same logic as the stationary debt structure, the operating lease contract with maturity $T_{L}$ pays a constant rent $r_{R}^{T}=\Omega_{R} / T_{L}$ per year under the stationary capital structure. The sum of all fractional claims $\rho_{R}^{t}$ for the lease contracts of all maturities outstanding equals $\rho_{R}$, implying that $\rho_{R}^{t}=\rho_{R} / T_{L}$. Note that $\rho_{R}$ is equivalent to the aggregate recovery rate of all outstanding lease contracts. Because the operating lease contract is continuously signed homogeneously over time, the recovery rate for every lease contract with maturity $t$ can be simply represented as $\rho_{R} / T_{L}$.

Based on these assumptions, the value of the outstanding lease, $L_{R}\left(V ; V_{B}, t\right)$, can be determined by integrating the lease flows over the period $T_{L}$ :

$$
\begin{aligned}
L_{R}\left(V ; V_{B}, t\right)= & \int_{0}^{T_{L}} l_{R}\left(V ; V_{B}, t\right) d t \\
= & \frac{\Omega_{R}}{r}\left(1-\frac{1-e^{-r T_{L}}}{r T_{L}}\right)-\frac{\Omega_{R}}{r}\left(J\left(T_{L}\right)-I\left(T_{L}\right)\right) \\
& +\frac{\rho_{R}}{T_{L}} \frac{\Omega_{R}}{r}\left(J\left(T_{L}\right)-I\left(T_{L}\right)\right) .
\end{aligned}
$$

The definitions of $I\left(T_{L}\right)$ and $J\left(T_{L}\right)$ are presented in the Appendix.

Previously, $\widetilde{V}_{B}$ was defined as the net asset value after bankruptcy and is represented as

$$
\widetilde{V}_{B}=(1-\alpha) V_{B}-\rho_{R} \Omega_{R}\left(\frac{1-e^{-r\left(T_{L}-\tau\right)}}{r}\right) .
$$

The 1 st term on the RHS is the asset value after bankruptcy costs, and the 2nd term represents the cash flow recovered by the lessor in the event of bankruptcy. As debt is junior to leases in terms of claim priority, debt holders receive the asset value less the bankruptcy costs and payments to the lessors. We assume that every outstanding lease contract recovers homogeneously in time and amount such that the aggregate recoveries are represented in terms of aggregate lease payments. Thus, the debt maturity is $t$, while the lease contract maturity is $T_{L}$. The difference in maturity incorporates the maturity of the lease contract into the debt 
contract. However, in calculating the loss to the lessor when the lessee defaults, we assume that on average the lessee defaults at the midpoint of the lease contract such that the average aggregate loss equals $\left(1-\rho_{R}\right) \Omega_{R}\left(\left(1-e^{-r\left(T_{L} / 2\right)}\right) / r\right)$. This assumption is justified by measuring the default time on average.

Given the above assumptions, we rewrite equation (10) as

$$
\begin{aligned}
d\left(V ; V_{B}, t\right)= & \frac{c(t)}{r}\left(1-e^{-r t}\right)-\frac{c(t)}{r}\left(G(t)-F(t) e^{-r t}\right) \\
& +e^{-r t} p(t)(1-F(t))+\rho_{D}(t)(1-\alpha) V_{B} G(t) \\
& -\rho_{D}(t) \rho_{R}\left(\frac{\Omega_{R}}{r}\right)\left(G(t)-e^{-r T_{L}} F(t)\right),
\end{aligned}
$$

where the 4th and 5th terms in expression (13) are the additional terms caused by bankruptcy. These terms represent the value that the debtholders recover after bankruptcy cost and reimbursement to the lessor. Let $D\left(V ; V_{B}, T_{D}\right)$ denote the total value of debt, when debt of maturity $T_{D}$ is issued. Integrating all outstanding debt, we obtain the debt value over period $T_{D}$ as

$$
\begin{aligned}
D\left(V ; V_{B}, T_{D}\right)= & \int_{0}^{T_{D}} d\left(V ; V_{B}, t\right) d t \\
= & \frac{C}{r}+\left(P-\frac{C}{r}\right)\left(\frac{1-e^{-r T_{D}}}{r T_{D}}-I\left(T_{D}\right)\right) \\
& +\left((1-\alpha) V_{B}-\frac{C}{r}\right) J\left(T_{D}\right) \\
& -\rho_{R}\left(\frac{\Omega_{R}}{r}\right)\left(J\left(T_{D}\right)-\frac{T_{L}}{T_{D}} I\left(T_{D}\right)\right) .
\end{aligned}
$$

The first 3 terms on the RHS of expression (14) are exactly the aggregate debt value in Leland and Toft (1996), equation (7), assuming debt is the firm's only financing resource. The 4th term represents the debt value loss because of its junior claim priority and is exactly the recovery value of the operating lease when the lessee defaults.

In most interest rate term structure models, such as Merton (1974), Black and Cox (1976), Brennan and Schwartz (1978), and Leland and Toft (1996), debt is the only financing instrument in the firm's liability structure. In our framework, we incorporate leasing into the debt value determination framework. From equation (14), we see that if the firm uses a lease in addition to debt, the debt value is reduced via the amount of outstanding lease contracts and the fraction of remaining payments the lessors recover. Thus, all relevant debt properties that include the yield spread, duration, and convexity are also affected by lease financing.

\section{Determining the Endogenous Default Boundary}

In traditional capital structure theory, the firm trades off the tax benefits and bankruptcy costs of debt financing. Since we incorporate lease financing into the capital structure decision, the tax deductibility benefit is composed of the interest rate expense of debt, the lease payments, and the depreciation expense. Following Leland (1994), the total market value of the firm equals the unleveraged firm value 
plus the tax benefit of debt and lease financing minus the bankruptcy cost during the observation period:

$$
\begin{aligned}
v\left(V ; V_{B}\right)= & V+t_{c}\left(\frac{C}{r}+\frac{\Omega_{R}}{r}\right)\left(1-\left(\frac{V_{B}}{V}\right)^{x}\right) \\
& -\left(\alpha V_{B}+\left(1-\rho_{R}\right) \Omega_{R}\left(\frac{1-e^{-r\left(T_{L} / 2\right)}}{r}\right)\right)\left(\frac{V_{B}}{V}\right)^{x},
\end{aligned}
$$

where $v\left(V ; V_{B}\right)$ is the market value of the firm, $V$ is the unleveraged firm value, $t_{c}$ is the corporate tax rate of the lessee, and $x=a+z$, where $a$ and $z$ are defined in the Appendix. The 2 nd term in equation (15) represents the tax benefits associated with interest rate expense, lease payments, and depreciation expense, given that the firm does not default. The 3rd term in equation (15) is the bankruptcy cost, given that the firm defaults and includes bankruptcy costs documented by Warner (1977) and the lessor's losses. In this setting, equation (15) is consistent with traditional capital structure trade-off theory that assumes the tax-shield benefit has a positive effect on firm value, while bankruptcy costs have a negative effect.

To determine the default boundary in this model, we apply the past-smoothing condition in Leland and Toft (1996) and solve the equation to determine the endogenous default boundary, $V_{B}$. Let

$$
\left.\frac{\partial E\left(V ; V_{B}, T\right)}{\partial V}\right|_{V=V_{B}}=0
$$

By solving equation (16), we find the endogenous bankruptcy boundary as

$$
V_{B}^{*}=\frac{\frac{\Omega_{R}}{r}\left(K_{1}^{T_{L}}-K_{2}^{T_{L}}\right)-K_{3}-K_{4}+M-\left(P-\frac{C}{r}\right) K_{1}^{T_{D}}-\left(\frac{C}{r}\right) K_{2}^{T_{D}}}{1+\alpha x-(1-\alpha) K_{2}^{T_{D}}}
$$

where the definitions of $K_{1}^{T}, K_{2}^{T}, K_{3}, K_{4}$, and $M$ are as listed in the Appendix. Equation (17) reduces to the boundary condition defined in Leland and Toft when the firm does not use lease financing. Equation (17) shows that when leases are included in the capital structure decision, the amount and recovery rate of the lease affect the firm's bankruptcy boundary. In contrast to Leland and Toft, our model points out that the default boundary is affected by $T_{D}, T_{L}$, coupon payment amount $C$, lease payment amount $\Omega_{R}$, and lease contract recovery rates $\rho_{R}$. In other words, the inclusion of lease financing decreases the bankruptcy boundary through the tax deductibility of lease payments; on the other hand, it also increases the bankruptcy boundary through the perpetual lease payments $\Omega_{R} / r$ and the default recovery rate of the lease contract. Therefore, the lease market condition also affects the lessee firm's capital structure decision.

\section{Comparative Statics and a Numerical Example}

In this section, we derive the comparative statics and conduct a numerical analysis of the lease rate term structure. Due to the high nonlinearity of equation (6), it is difficult to determine the sign of the comparative statics of $r_{R}^{t}$ with respect to the variables exactly. Therefore, we derive the comparative statics of $r_{R}^{t}$ in terms 
of the sign of the comparative statics of $V_{B}$. By this method, we can see that most of the comparative statics of $r_{R}^{t}$ are determined by the comparative statics of $V_{B}$. For the numerical example, we set the firm's initial asset value to $\$ 100$ and determine the issuing coupon and principle value, assuming debt is issued at par. ${ }^{13}$ We examine how the lease rate term structure is affected by the lease contract recovery rate, the lessee's risk aversion attitude toward lease market uncertainty, the service flow volatility of the leased asset, the lessee's corporate tax rate, and the lessee's asset volatility. Since the lease maturity may not equal the debt maturity, we also discuss the relative maturity term changes of the lease and debt contracts. Our discussion provides another dimension in examining the interaction between lease financing and debt financing and how the maturity term of debt financing affects the lease rent. In addition, the lease market determines the default risk premium on the lease based on the lessee's default risk. Therefore, the determination of the lease rate term structure becomes a simultaneous equation problem concerning the lessee's financing decision and the competitive lease market.

\section{A. The Impact of the Expected Lease Default Recovery Rate}

We first examine the lease term structure under various assumptions regarding the potential default recovery rate. In order to determine the sign of the comparative static of $r_{R}^{t}$ with respect to $\rho_{R}^{t}$ (the recovery rate), we show in the Appendix the relation between $\partial r_{R}^{t} / \partial \rho_{R}^{t}$ and $\partial V_{B} / \partial \rho_{R}^{t}$. Thus, Table 1 shows the

TABLE 1

Impact of the Lease Recovery Rate on the Lease Rate Term Structure

Table 1 displays the lease rate term structure, default boundary values, and leverage ratios for lease maturities ( $T_{L}$ ) ranging from 2.5 to 20 years assuming the risk-free interest rate $r=7.5 \%$, the bankruptcy costs $\alpha=50 \%$, the lessor's corporate tax rate $\operatorname{TAX}_{C}=35 \%$, the lessee's corporate tax rate $t_{C}=35 \%$, the firm's asset volatility $\sigma_{V}=20 \%$, the firm's payout rate $\delta_{V}=7 \%$, the drift term of the service flow process $\mu_{S}=6 \%$, the depreciation rate for the service flow $q=5 \%$, the initial service flow $S_{0}=1$, the risk aversion $\delta=0.83$, and the level that accounting depreciation is scaled to economic depreciation $\chi=0.5$.

\begin{tabular}{|c|c|c|c|c|c|c|c|c|c|c|c|c|}
\hline \multirow[b]{2}{*}{$T_{L}$} & \multicolumn{3}{|c|}{$\rho_{R}=0$} & \multicolumn{3}{|c|}{$\rho_{R}=0.2$} & \multicolumn{3}{|c|}{$\rho_{R}=0.4$} & \multicolumn{3}{|c|}{$\rho_{R}=0.6$} \\
\hline &  & 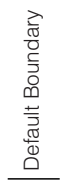 & 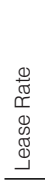 & 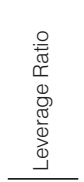 & 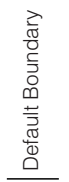 & 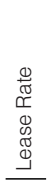 & 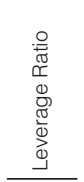 &  & 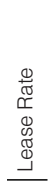 & 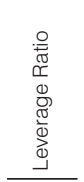 & 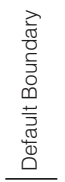 & 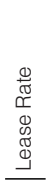 \\
\hline \multicolumn{13}{|c|}{$\underline{\text { Panel } A .} T_{D}=20$ years } \\
\hline 2.5 & $57.03 \%$ & 41.31 & 1.02 & $55.45 \%$ & 41.58 & 1.02 & $53.84 \%$ & 41.84 & 1.02 & $52.60 \%$ & 42.48 & 1.02 \\
\hline 5 & $56.35 \%$ & 40.90 & 1.04 & $54.73 \%$ & 41.23 & 1.04 & $53.48 \%$ & 41.95 & 1.04 & $51.39 \%$ & 41.94 & 1.04 \\
\hline 10 & $56.05 \%$ & 40.47 & 1.13 & $54.03 \%$ & 40.71 & 1.13 & $52.38 \%$ & 41.32 & 1.13 & $50.70 \%$ & 41.95 & 1.13 \\
\hline 15 & $55.65 \%$ & 39.71 & 1.21 & $53.70 \%$ & 40.27 & 1.21 & $51.29 \%$ & 40.46 & 1.21 & $49.26 \%$ & 41.03 & 1.21 \\
\hline 20 & $55.23 \%$ & 38.84 & 1.27 & $53.36 \%$ & 39.71 & 1.28 & $51.03 \%$ & 40.22 & 1.29 & $48.65 \%$ & 40.75 & 1.29 \\
\hline \multicolumn{13}{|c|}{$\underline{\text { Panel B. }} T_{D}=5$ years } \\
\hline 2.5 & $36.53 \%$ & 34.51 & 1.01 & $35.73 \%$ & 34.66 & 1.01 & $34.92 \%$ & 34.82 & 1.01 & $34.11 \%$ & 34.97 & 1.01 \\
\hline 5 & $35.24 \%$ & 33.45 & 1.03 & $35.30 \%$ & 34.14 & 1.03 & $35.36 \%$ & 34.82 & 1.03 & $34.51 \%$ & 34.65 & 1.03 \\
\hline 10 & $34.84 \%$ & 33.00 & 1.09 & $34.94 \%$ & 33.41 & 1.09 & $35.51 \%$ & 34.26 & 1.09 & $35.63 \%$ & 34.67 & 1.09 \\
\hline 15 & $33.93 \%$ & 31.88 & 1.14 & $35.09 \%$ & 33.09 & 1.15 & $35.36 \%$ & 33.44 & 1.15 & $36.63 \%$ & 34.65 & 1.16 \\
\hline 20 & $33.46 \%$ & 31.13 & 1.20 & $34.33 \%$ & 31.92 & 1.20 & $35.75 \%$ & 33.14 & 1.21 & $37.78 \%$ & 34.81 & 1.23 \\
\hline
\end{tabular}

\footnotetext{
${ }^{13}$ To conform with previous studies, we use the parameter values from Leland and Toft (1996).
} 
impact of changes in $\rho_{R}$ on $V_{B}$. For cases when the lessee issues long-term debt (Panel A), we find that $\left(\partial V_{B} / \partial \rho_{R}^{t}\right)>0$. However, under the assumption that the lessee issues short-term debt (Panel B), we see a nonlinear relation depending upon the lease maturity $\left(T_{L}\right)$.

Numerically, Table 1 confirms these comparative statics by showing the lease rates for various expected lease recovery rates $\left(\rho_{R}\right)$ and lease maturities $\left(T_{L}\right)$, assuming the lessee issues debt with maturity of 20 years (Panel A) and 5 years (Panel B). Panels A and B show the impact of changing the expected lease recovery rate from $0 \%$ to $60 \%$. Not surprisingly, for short-term leases $\left(T_{L}=2.5\right.$ years $)$ the lease rate is not sensitive to changes in the expected default recovery rate. However, it is interesting to note that the lease rate is only marginally increasing with the expected default recovery rate for long-term lease contracts $\left(T_{L}=20\right.$ years). For example, with $\rho_{R}=0.6$ the lease rate is only $1.6 \%$ higher than when $\rho_{R}=0$ (Panel A, $T_{L}=20$ years).

The rationale for the marginal effect of the expected recovery rate on the lease term structure becomes clear by evaluating the effects of $\rho_{R}$ on the lessee's optimal bankruptcy boundary condition (equation (17)) through the components $K_{4}, M$, and $\Omega_{R}$ (as defined in the Appendix). We see that $\rho_{R}$ affects $V_{B}^{*}$ in 2 directions: First, an increase in $\rho_{R}$ results in an increase in $V_{B}^{*}$ (through $K_{4}$ and $M$ ). Second, an increase in $\rho_{R}$ causes a decrease in $V_{B}^{*}$ through $\Omega_{R}$. However, the direction of causation is complicated and nonlinear, as $\Omega_{R}$ is also affected by $V_{B}^{*}$ (because the components $G(t)$ and $F(t)$ are functions of $V_{B}^{*}$ ). As a result, the net effect of $\rho_{R}^{t}$ on $r_{R}^{t}$ is minimal.

The increase (albeit small) in the lease rate as the expected recovery rate increases is directly counter to the findings of Grenadier (1996), who shows that the term structure of the lease rates decreases strictly with the recovery rate. Thus, the relative lack of sensitivity to changes in the expected recovery rate points out the difference between the endogenous default credit risk model and the exogenous default credit risk model, especially under the competitive lease market assumption.

\section{B. The Impact of the Amount of Debt}

In our model, the optimal amount of debt is determined endogenously by shareholders under the trade-off between the tax benefit of debt and the bankruptcy cost, which includes the settlement cost and the possible losses for lessors. In Table 1 , for $T_{D}=5$ years, the leverage ratio, which is defined as the debt value over the firm value, is optimally determined in the range between $33 \%$ and $38 \%$ even when the expected lease default recovery rate changes from 0 to 0.6 . Similarly, for $T_{D}=20$ years, the leverage ratio is stable and located in the range between $48 \%$ and $55 \%$. If we examine the case when $T_{D}=20$ years and $\rho_{R}=0.6$, the leverage ratio decreases with lease maturity while the lease rate increases with lease maturity. This result corresponds to the traditional argument in financial theory that debt and lease are substitutes. As the lease maturity increases, the value of lease increases, and it leads to the decrease of the leverage ratio. 


\section{The Impact of Lease Maturity}

Table 1 also highlights the impact of lease maturity. Not surprisingly, we note that as the lease maturity increases, the lease rate increases. For example, column 1 of Panel A indicates that the market rent for a 20 -year lease is $25 \%$ greater than the market rent for a 2.5-year lease. This finding is consistent with a premium existing for longer-term, fixed-rate contracts.

\section{The Impact of Debt Maturity}

As developed in Section IV, the lessee's capital structure will also impact the lease term structure. We highlight the impact of financing decisions on lease rates by examining the lease term structure under the assumption that the lessee issues short-term or long-term debt. Panel A of Table 1 contains the expected lease rates assuming that the lessee issues long-term (20-year) debt, while Panel $\mathrm{B}$ reports the lease rates assuming the use of short-term (5-year) debt. Holding all else constant, it appears that the lease rate is positively related to lessee debt maturity. For example, when debt maturity is 20 years the lease rate is $5.8 \%$ higher than when the lessee debt maturity is 5 years (assuming the lease maturity is 20 years and the recovery rate is 0 ).

\section{E. The Impact of Risk Aversion}

To understand the impact of risk aversion on lease rates, we differentiate equation (6) with respect to $\delta$ :

$$
\begin{aligned}
\frac{\partial r_{R}^{t}}{\partial \delta}= & \underbrace{\left(1-e^{-r t}\right)}_{\oplus} \\
& \times\{\left(\frac{\partial r_{N}^{t}}{\partial \delta}\right) \underbrace{\left(\left(1-e^{-r t}\right)-\left(1-\rho_{R}^{t}\right)\left(G(t)-F(t) e^{-r t}\right)\right]^{-1}}_{\oplus} \\
& +\underbrace{r_{N}^{t}\left[\left(1-e^{-r t}\right)-\left(1-\rho_{R}^{t}\right)\left(G(t)-F(t) e^{-r t}\right)\right]^{-2}}_{\oplus} \\
& \underbrace{\left(1-\rho_{R}^{t}\right)\left(\frac{\partial G(t)}{\partial V_{B}}-\frac{\partial F(t)}{\partial V_{B}} e^{-r t}\right)}_{\oplus}\left(\frac{\partial V_{B}}{\partial \delta}\right)\} .
\end{aligned}
$$

Note that the sign of $\partial r_{R}^{t} / \partial \delta$ is determined by $\left(\partial r_{N}^{t} / \partial \delta\right)$ and $\left(\partial V_{B} / \partial \delta\right)$. From equation (4) in Section III.A, we note that when $\left(\mu_{S}-\delta \sigma_{S}-q-r\right) t$ is small, $e^{\left(\mu_{S}-\delta \sigma_{S}-q-r\right) t}-1$ can be approximated by $\left(\mu_{S}-\delta \sigma_{S}-q-r\right) t$ and $r_{N}^{t}=S(0)$ $\left(r /\left(1-e^{-r t}\right)\right) t$ such that $r_{N}^{t}$ is only slightly affected by $\delta$. However, when $\left(\mu_{S}-\right.$ $\left.\delta \sigma_{S}-q-r\right) t$ is not small, $\delta$ has a noticeable affect on $r_{N}^{t}$.

To illustrate these effects, in Table 2 and Figure 1 we examine the impact of risk aversion in terms of the market price of risk $(\delta)$ when the lessee issues longterm debt (Panel A) and short-term debt (Panel B). As in Table 1, the lease rates 
increase with the lease contract's time to maturity. Furthermore, the lease rate term structure decreases as the degree of risk aversion increases. For example, the lease rate is $22 \%$ lower when $\delta=0.8$ versus when $\delta=0.2$ (Panel A, $T_{L}=20$ years). This result is consistent with Clapham and Gunnelin (2003), who show the same result assuming stochastic interest rates, but without default risk. Intuitively, the results in Table 2 arise from the fact that the drift rate of the risk-neutral service flow process declines due to the increase in the market price of risk. Thus, the present value of future lease service flows declines regardless of how the lessee firm adjusts its endogenous default level through choice of debt maturity.

\section{TABLE 2}

The Impact of Risk Aversion on the Lease Rate Term Structure

Table 2 displays the lease rate term structure and default boundary values for lease maturities $\left(T_{L}\right)$ ranging from 2.5 to 20 years assuming the risk-free interest rate $r=7.5 \%$, the bankruptcy costs $\alpha=50 \%$, the lessor's corporate tax rate $\operatorname{TAX}_{C}=35 \%$, the lessee's corporate tax rate $t_{C}=35 \%$, the firm's asset volatility $\sigma_{V}=20 \%$, the firm's payout rate $\delta_{V}=7 \%$, the drift term of the service flow process $\mu_{S}=6 \%$, the depreciation rate for the service flow $q=5 \%$, the initial service flow $S_{0}=1$, the recovery rate $\rho_{R}=0.62$, and the level that accounting depreciation is scaled to economic depreciation $\chi=0.5$.

\begin{tabular}{|c|c|c|c|c|c|c|c|c|}
\hline \multirow[b]{2}{*}{$T_{L}$} & \multicolumn{2}{|c|}{$\delta=0.2$} & \multicolumn{2}{|c|}{$\delta=0.4$} & \multicolumn{2}{|c|}{$\delta=0.6$} & \multicolumn{2}{|c|}{$\delta=0.8$} \\
\hline & $\begin{array}{c}\text { Default } \\
\text { Boundary }\end{array}$ & $\begin{array}{c}\text { Lease } \\
\text { Rate } \\
\end{array}$ & $\begin{array}{c}\text { Default } \\
\text { Boundary }\end{array}$ & $\begin{array}{c}\text { Lease } \\
\text { Rate } \\
\end{array}$ & $\begin{array}{c}\text { Default } \\
\text { Boundary }\end{array}$ & $\begin{array}{l}\text { Lease } \\
\text { Rate } \\
\end{array}$ & $\begin{array}{c}\text { Default } \\
\text { Boundary }\end{array}$ & $\begin{array}{l}\text { Lease } \\
\text { Rate } \\
\end{array}$ \\
\hline \multicolumn{9}{|c|}{ Panel $A . T_{D}=20$ years } \\
\hline 2.5 & 42.08 & 1.05 & 42.40 & 1.04 & 42.34 & 1.03 & 42.29 & 1.02 \\
\hline 5 & 41.78 & 1.12 & 42.02 & 1.10 & 42.27 & 1.07 & 42.15 & 1.05 \\
\hline 10 & 41.57 & 1.30 & 41.26 & 1.24 & 41.72 & 1.19 & 41.82 & 1.14 \\
\hline 15 & 40.90 & 1.48 & 40.75 & 1.39 & 41.02 & 1.30 & 41.34 & 1.23 \\
\hline 20 & 40.14 & 1.66 & 40.13 & 1.52 & 40.58 & 1.41 & 40.73 & 1.30 \\
\hline \multicolumn{9}{|c|}{ Panel B. $T_{D}=5$ years } \\
\hline 2.5 & 35.17 & 1.05 & 35.14 & 1.04 & 35.10 & 1.03 & 35.07 & 1.02 \\
\hline 5 & 34.43 & 1.11 & 34.82 & 1.09 & 34.77 & 1.06 & 35.16 & 1.04 \\
\hline 10 & 34.44 & 1.25 & 34.38 & 1.20 & 34.77 & 1.15 & 34.72 & 1.10 \\
\hline 15 & 34.38 & 1.41 & 33.90 & 1.32 & 34.73 & 1.25 & 35.13 & 1.17 \\
\hline 20 & 33.63 & 1.57 & 34.03 & 1.45 & 34.44 & 1.34 & 34.41 & 1.24 \\
\hline
\end{tabular}

\section{F. The Impact of Service Flow Volatility}

In Table 3 and Figure 2, we examine the impact of changes in the service flow volatility $\left(\sigma_{S}\right)$ on the lease term structure. Differentiating equation (6) with respect to $\sigma_{S}$ provides an indication of the expected impact of the service flow volatility on the lease rate:

$$
\begin{aligned}
\frac{\partial r_{R}^{t}}{\partial \sigma_{S}}= & \underbrace{\left(1-e^{-r t}\right)}_{\oplus}\{\left(\frac{\partial r_{N}^{t}}{\partial \sigma_{S}}\right) \underbrace{\left[\left(1-e^{-r t}\right)-\left(1-\rho_{R}^{t}\right)\left(G(t)-F(t) e^{-r t}\right)\right]^{-1}}_{\oplus} \\
& +\underbrace{r_{N}^{t}\left[\left(1-e^{-r t}\right)-\left(1-\rho_{R}^{t}\right)\left(G(t)-F(t) e^{-r t}\right)\right]^{-2}}_{\oplus} \\
& \underbrace{(1-)}_{\left.\left.\oplus \rho_{R}^{t}\right)\left(\frac{\partial G(t)}{\partial V_{B}}-\frac{\partial F(t)}{\partial V_{B}} e^{-r t}\right)\left(\frac{\partial V_{B}}{\partial \sigma_{S}}\right)\right\} .}
\end{aligned}
$$


FIGURE 1

The Impact of Risk Aversion

Figure 1 shows the impact of changes in risk aversion $(\delta)$ on the lease term structure.

Graph A. The Impact of Risk Aversion on the Lease Rate Term Structure $\left(T_{D}=20\right.$ years)

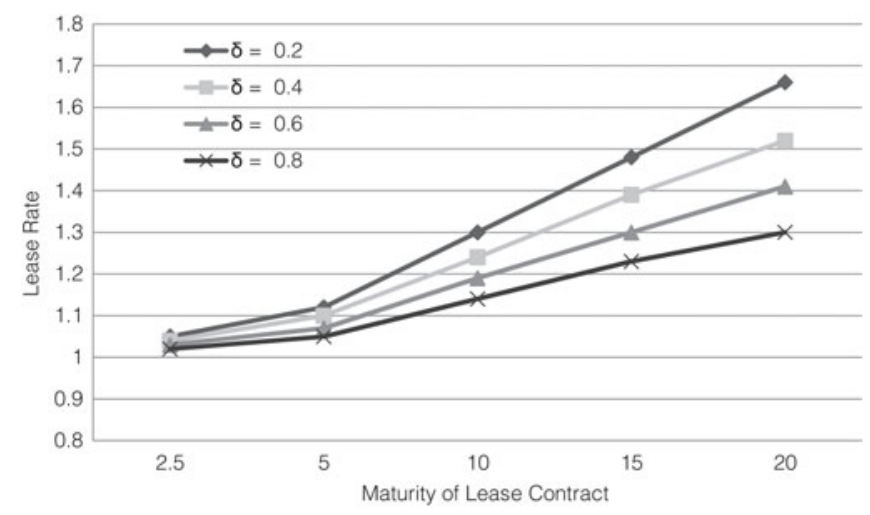

Graph B. The Impact of Risk Aversion on the Lease Rate Term Structure ( $T_{D}=5$ years)

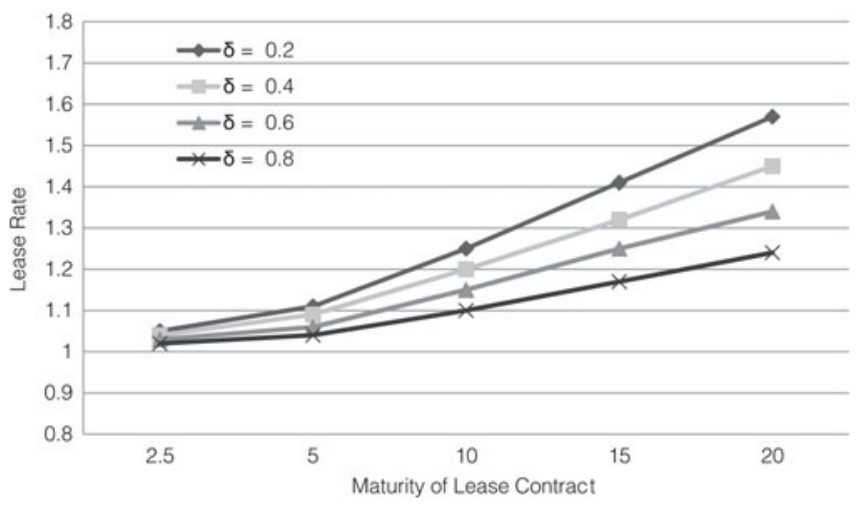

Again, note that the sign of $\left(\partial r_{R}^{t} / \partial \delta\right)$ is determined by $\left(\partial r_{N}^{t} / \partial \sigma_{S}\right)$ and $\left(\partial V_{B} / \partial \delta\right)$. Similarly, when $\left(\mu_{S}-\delta \sigma_{S}-q-r\right) t$ is small, $e^{\left(\mu_{S}-\delta \sigma_{S}-q-r\right) t}-1$ can be approximated by $\left(\mu_{S}-\delta \sigma_{S}-q-r\right) t$ and $r_{N}^{t}=S(0)\left(r /\left(1-e^{-r t}\right)\right) t$ such that $r_{N}^{t}$ is only slightly affected by $\sigma_{S}$. However, when $\left(\mu_{S}-\delta \sigma_{S}-q-r\right) t$ is not small, $\sigma_{S}$ has a noticeable effect on $r_{N}^{t}$.

Numerically, we find in Table 3 and Figure 2 that the lease rate is decreasing as the volatility of service flow increases. The lease rate increases because the increase in service flow volatility decreases the drift rate of the service flow process under a risk-neutral measure, thus decreasing the present value of future lease service flows. In this regard, the lessee firm's default risk has little impact on the lease rate term structure when the lease rate term structure is mainly affected by the service flow process (holding all else constant). In addition, comparison of the lease rates in Panels A and B reveals that lease rate changes in response to changes in service flow volatility are not sensitive to the lessee's debt maturity, holding all else constant. For example, the lease rate is $71 \%$ lower when $\sigma_{S}=0.8$ 


\section{TABLE 3}

The Impact of Service Flow Volatility on the Lease Rate Term Structure

Table 3 displays the lease rate term structure and default boundary value for lease maturities $\left(T_{L}\right)$ ranging from 2.5 to 20 years assuming the risk-free interest rate $r=7.5 \%$, the bankruptcy costs $\alpha=50 \%$, the lessor's corporate tax rate $\operatorname{TAX}_{C}=35 \%$, the lessee's corporate tax rate $t_{c}=35 \%$, the firm's payout rate $\delta_{V}=7 \%$, the drift term of the service flow process $\mu_{S}=6 \%$, the depreciation rate for the service flow $q=5 \%$, the initial service flow $S_{0}=1$, the risk aversion $\delta=0.83$, the recovery rate $\rho R=0.62$, and the level that accounting depreciation is scaled to economic depreciation $\chi=0.5$.

\begin{tabular}{|c|c|c|c|c|c|c|c|c|}
\hline \multirow[b]{2}{*}{$T_{L}$} & \multicolumn{2}{|c|}{$\sigma_{S}=0.2$} & \multicolumn{2}{|c|}{$\sigma_{S}=0.4$} & \multicolumn{2}{|c|}{$\sigma_{S}=0.6$} & \multicolumn{2}{|c|}{$\sigma_{S}=0.8$} \\
\hline & $\begin{array}{c}\text { Default } \\
\text { Boundary } \\
\end{array}$ & $\begin{array}{c}\text { Lease } \\
\text { Rate } \\
\end{array}$ & $\begin{array}{c}\text { Default } \\
\text { Boundary } \\
\end{array}$ & $\begin{array}{c}\text { Lease } \\
\text { Rate }\end{array}$ & $\begin{array}{c}\text { Default } \\
\text { Boundary } \\
\end{array}$ & $\begin{array}{l}\text { Lease } \\
\text { Rate }\end{array}$ & $\begin{array}{c}\text { Default } \\
\text { Boundary } \\
\end{array}$ & $\begin{array}{c}\text { Lease } \\
\text { Rate }\end{array}$ \\
\hline \multicolumn{9}{|c|}{$\underline{\text { Panel } A . T_{D}=20 \text { years }}$} \\
\hline 2.5 & 42.37 & 0.87 & 42.43 & 0.73 & 42.65 & 0.61 & 42.99 & 0.52 \\
\hline 5 & 42.31 & 0.79 & 42.70 & 0.57 & 42.75 & 0.43 & 43.05 & 0.34 \\
\hline 10 & 42.36 & 0.69 & 42.80 & 0.42 & 42.87 & 0.29 & 43.26 & 0.22 \\
\hline 15 & 42.50 & 0.63 & 42.87 & 0.35 & 43.01 & 0.24 & 43.06 & 0.18 \\
\hline 20 & 42.33 & 0.59 & 42.71 & 0.32 & 43.28 & 0.22 & 42.97 & 0.17 \\
\hline \multicolumn{9}{|c|}{ Panel B. $T_{D}=5$ years } \\
\hline 2.5 & 36.00 & 0.87 & 36.48 & 0.73 & 36.61 & 0.61 & 37.24 & 0.52 \\
\hline 5 & 35.99 & 0.78 & 36.90 & 0.56 & 37.52 & 0.43 & 37.79 & 0.34 \\
\hline 10 & 36.48 & 0.66 & 37.98 & 0.41 & 38.30 & 0.28 & 38.24 & 0.22 \\
\hline 15 & 37.02 & 0.60 & 38.20 & 0.34 & 38.59 & 0.23 & 39.00 & 0.18 \\
\hline 20 & 37.29 & 0.56 & 38.11 & 0.31 & 38.52 & 0.21 & 38.95 & 0.16 \\
\hline
\end{tabular}

than when $\sigma_{S}=0.2$ (when $T_{L}=20$ years) regardless of whether the lessee's debt maturity is 5 or 20 years.

\section{G. The Impact of Asset Volatility}

In Table 4 and Figure 3, we show the impact of changes to the lessee's asset volatility on the lease rate term structure. To determine the expected effect of changes in asset volatility on the lease rate, we differentiate equation (6) with respect to $\sigma_{V}$ :

$$
\begin{aligned}
& \frac{\partial r_{R}^{t}}{\partial \sigma_{V}}= \underbrace{-r_{N}^{t}\left(1-e^{-r t}\right)\left[\left(1-e^{-r t}\right)-\left(1-\rho_{R}^{t}\right)\left(G(t)-F(t) e^{-r t}\right)\right]^{-2}}_{\ominus} \\
& \times[-\underbrace{\left(1-\rho_{R}^{t}\right)\left(\frac{\partial G(t)}{\partial V_{B}}-\frac{\partial F(t)}{\partial V_{B}} e^{-r t}\right)}_{\oplus}\left(\frac{\partial V_{B}}{\partial \sigma_{V}}\right)] .
\end{aligned}
$$

The sign of $\left(\partial r_{R}^{t} / \partial \sigma_{V}\right)$ is determined by $\left(\partial V_{B} / \partial \sigma_{V}\right)$. Consistent with the basic conclusion of structural credit risk models, the numerical results in Table 4 and Figure 3 show that the lease rate increases as the lessee's asset volatility increases. Intuitively, the increase in the asset's risk level should increase the lease rent, since holding a lease contract is analogous to selling a put option on the asset. Thus, as the volatility of the underlying asset increases, the premium of the put option increases; therefore, the lease rent will increase. Comparing the percentage increase in Panels A and B reveals that the lease rate is more sensitive to asset volatility when the lessee utilizes long-term debt than when it uses short-term debt. For example, when $T_{D}=20$ years (Panel A), the 20-year contract lease rate 
FIGURE 2

The Impact of Service Flow Volatility

Figure 2 shows the impact of changes in service flow volatility $\left(\sigma_{S}\right)$ on the lease term structure.

Graph A. The Impact of Service Flow Volatility on the Lease Rate Term Structure ( $T_{D}=20$ years)

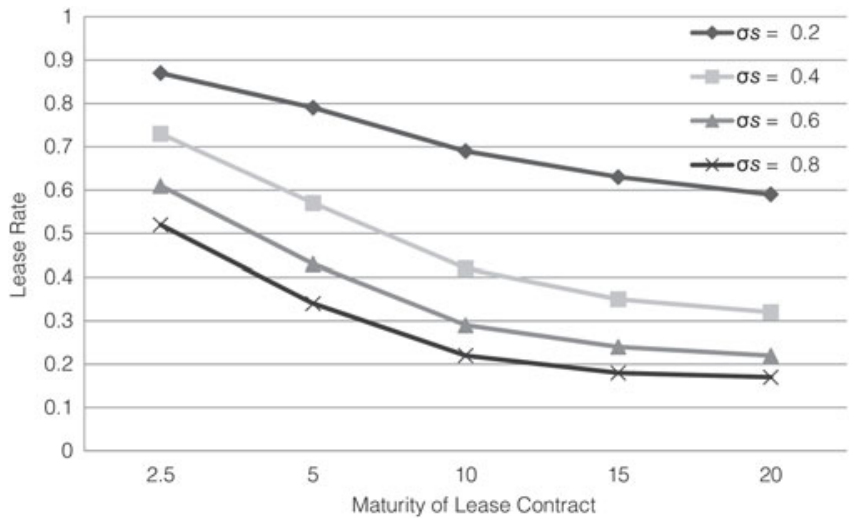

Graph B. The Impact of Service Flow Volatility on the Lease Rate Term Structure ( $T_{D}=5$ years)

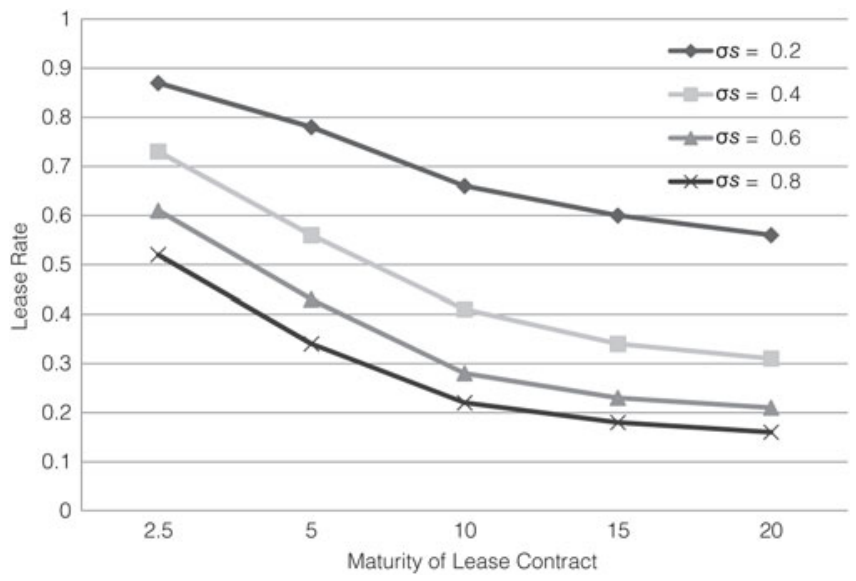

increases $94 \%$ as asset volatility increases from 0.1 to 0.7 . However, over the same asset volatility range, the 20-year contract lease rate increases $73 \%$ when $T_{D}=5$ years (Panel B).

\section{H. The Impact of Debt Default Probability}

Table 5 shows the relation between the probability of default on the lessee's existing debt and the lease term structure. In Panel A, we examine the case where the firm issues short-term debt $\left(T_{D}=5\right.$ years), and Panel B shows the case where the firm issues long-term debt $\left(T_{D}=20\right.$ years). The row in italics corresponds to the term structure implied by our endogenous default model. Using this as the base case, we change the default boundary to highlight the impact of the probability of debt default. The results show that the lease rate increases as the default 


\section{TABLE 4}

The Impact of Asset Volatility on the Lease Rate Term Structure

\begin{tabular}{|c|c|c|c|c|c|c|c|c|}
\hline \multirow[b]{2}{*}{$\underline{T_{L}}$} & \multicolumn{2}{|c|}{$\sigma_{V}=0.1$} & \multicolumn{2}{|c|}{$\sigma_{V}=0.3$} & \multicolumn{2}{|c|}{$\sigma_{V}=0.5$} & \multicolumn{2}{|c|}{$\sigma_{V}=0.7$} \\
\hline & $\begin{array}{c}\text { Default } \\
\text { Boundary } \\
\end{array}$ & $\begin{array}{c}\text { Lease } \\
\text { Rate } \\
\end{array}$ & $\begin{array}{c}\text { Default } \\
\text { Boundary } \\
\end{array}$ & $\begin{array}{l}\text { Lease } \\
\text { Rate } \\
\end{array}$ & $\begin{array}{c}\text { Default } \\
\text { Boundary } \\
\end{array}$ & $\begin{array}{l}\text { Lease } \\
\text { Rate } \\
\end{array}$ & $\begin{array}{c}\text { Default } \\
\text { Boundary } \\
\end{array}$ & $\begin{array}{c}\text { Lease } \\
\text { Rate } \\
\end{array}$ \\
\hline \multicolumn{9}{|c|}{ Panel $A . T_{D}=20$ years } \\
\hline $\begin{array}{l}2.5 \\
5 \\
10 \\
15 \\
20\end{array}$ & $\begin{array}{l}58.50 \\
58.22 \\
57.33 \\
57.30 \\
57.60\end{array}$ & $\begin{array}{l}1.01 \\
1.03 \\
1.08 \\
1.13 \\
1.18\end{array}$ & $\begin{array}{l}33.50 \\
33.70 \\
33.29 \\
32.33 \\
31.56\end{array}$ & $\begin{array}{l}1.02 \\
1.07 \\
1.21 \\
1.34 \\
1.44\end{array}$ & $\begin{array}{l}25.92 \\
25.56 \\
24.05 \\
22.64 \\
21.32\end{array}$ & $\begin{array}{l}1.05 \\
1.18 \\
1.45 \\
1.66 \\
1.82\end{array}$ & $\begin{array}{l}19.76 \\
20.35 \\
19.58 \\
17.48 \\
15.72\end{array}$ & $\begin{array}{l}1.09 \\
1.33 \\
1.78 \\
2.08 \\
2.29\end{array}$ \\
\hline \multicolumn{9}{|c|}{ Panel B. $T_{D}=5$ years } \\
\hline $\begin{array}{l}2.5 \\
5 \\
10 \\
15 \\
20\end{array}$ & $\begin{array}{l}53.10 \\
52.66 \\
52.75 \\
52.84 \\
52.84\end{array}$ & $\begin{array}{l}1.01 \\
1.03 \\
1.07 \\
1.11 \\
1.15\end{array}$ & $\begin{array}{l}28.49 \\
28.31 \\
28.18 \\
27.53 \\
26.21\end{array}$ & $\begin{array}{l}1.02 \\
1.05 \\
1.16 \\
1.27 \\
1.35\end{array}$ & $\begin{array}{l}26.23 \\
25.69 \\
23.63 \\
20.65 \\
17.40\end{array}$ & $\begin{array}{l}1.05 \\
1.19 \\
1.44 \\
1.60 \\
1.68\end{array}$ & $\begin{array}{l}22.24 \\
22.55 \\
19.32 \\
15.25 \\
10.42\end{array}$ & $\begin{array}{l}1.12 \\
1.38 \\
1.77 \\
1.98 \\
1.99\end{array}$ \\
\hline
\end{tabular}

probability increases in every case. In other words, riskier firms (i.e., those firms with higher probabilities of default) face higher equilibrium lease rates. For example, in the case where $T_{D}=T_{L}=5$ years, we see that the lease rate increases by $18 \%$ as the default probability increases from $7.65 \%$ to $50.25 \%$.

In addition, Table 5 shows the impact of changes in the firm's capital structure that result from the increase in firm risk, holding the lease and debt maturities constant. For example, when the firm uses long-term debt $\left(T_{D}=20\right.$ years), the firm's capital structure $(D / V)$ is not sensitive to changes in the default boundary conditions. However, firm capital structure shows greater sensitivity to changes in the default boundary when the firm uses short-term debt $\left(T_{D}=5\right.$ years $)$.

\section{The Impact of Tax Rates and Tax Policy}

In this section, we utilize our model to highlight the complex interactions that arise resulting from differences in lessee and lessor tax rates as well as from changes in overall tax policy. Recall from Section III, we noted that the equilibrium lease rate is a function of both the marginal corporate tax rate $\left(\mathrm{TAX}_{c}\right)$ as well as the tax treatment of economic depreciation $(q)$ as reflected in the parameter $(\chi)$. As noted above, $\chi=1$ reflects the case that accounting and economic depreciation are equivalent, while $\chi<1$ reflects the condition that the tax deduction associated with depreciation is less than that of the full economic depreciation. Thus, by varying $\chi$, we can show the impact on lease rates of changes in the depreciation schedules associated with real property.

Table 6 reports the numerical estimates of the lease rates based on changes to the lessor's and lessee's corporate tax rate as well as $\chi$. We first examine the lessee's incentive to use leasing when the lessee's corporate tax rate is higher than the lessor's. The results clearly indicate that the equilibrium lease rate is higher 
FIGURE 3

The Impact of Asset Volatility

Figure 3 shows the impact of changes in asset volatility $\left(\sigma_{V}\right)$ on the lease term structure.

Graph A. The Impact of Asset Volatility on the Lease Rate Term Structure $\left(T_{D}=20\right.$ years)

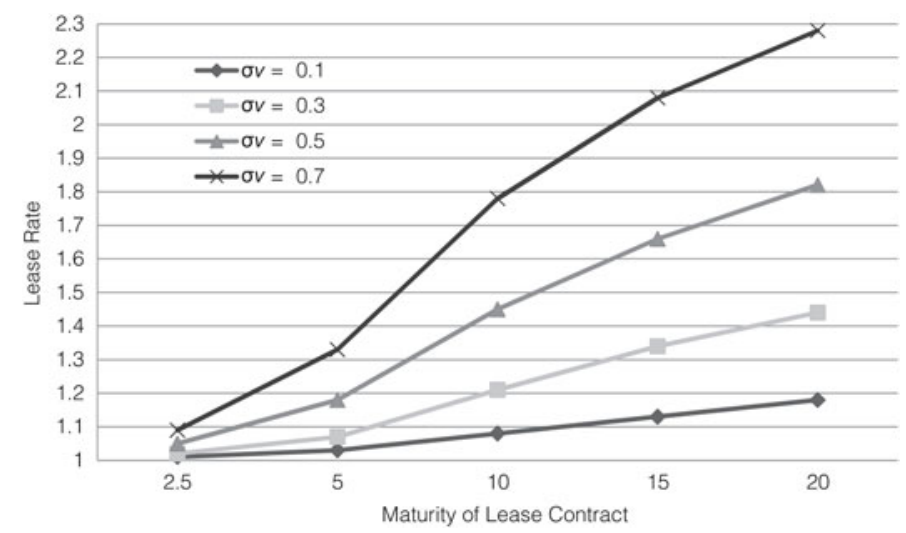

Graph B. The Impact of Asset Volatility on the Lease Rate Term Structure $\left(T_{D}=5\right.$ years)

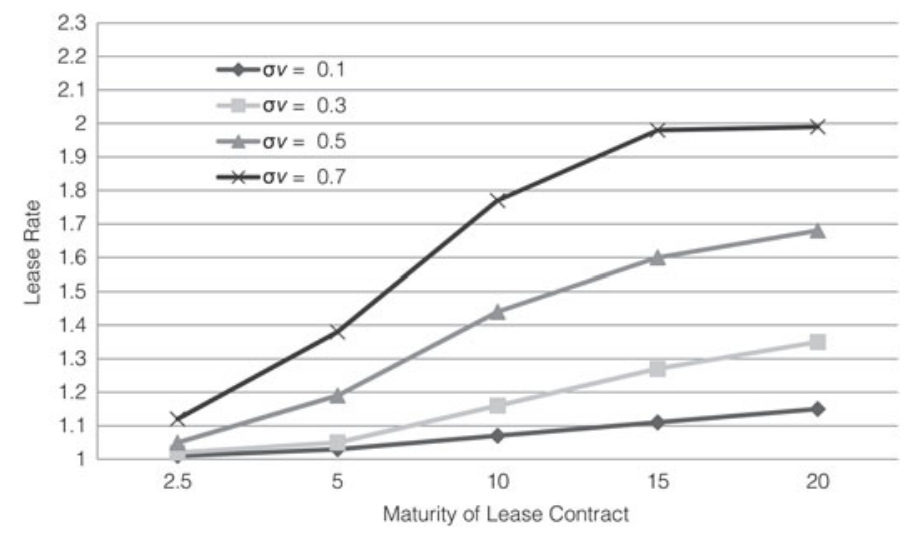

when the lessee's tax rate is greater than the lessor's tax rate. For example, in Panel A the lease rate is $32 \%$ higher when the lessee's tax rate is $70 \%$ and the lessor's tax rate is $10 \%$. The higher equilibrium lease rate results from the incentive from the high marginal tax rate to utilize more debt because of its higher tax-shield benefit. The increase in the utilization of debt then increases the default probability. The increase in the overall default likelihood results in a higher default premium in the lease rent. Therefore, the lease rent increases with the lessee's corporate tax rate.

Looking now at the impact of the lessor's marginal tax rate, we see that lease rates decline as the lessor's marginal tax rate increases-all else being equal. For example, looking across each row in Panel A of Table 6 we see that the lease rate is approximately $6 \%$ lower when the lessor's marginal tax rate is $70 \%$ compared to when the lessor's marginal tax rate is $10 \%$.

Finally, turning to the impact of the government's tax policy regarding the depreciation shelter, we see the effect of changing the depreciable life for 


\section{TABLE 5}

\section{The Impact of Probability of Debt Default on the Lease Rate Term Structure}

Table 5 examines the relation between the lease rate term structure and the probability of default on the lessee's debt. We assume the risk-free interest rate $r=7.5 \%$, the bankruptcy costs $\alpha=50 \%$, the lessor's corporate tax rate $\mathrm{TAX}_{c}=35 \%$, the lessee's corporate tax rate $t_{c}=35 \%$, the firm's asset volatility $\sigma_{v}=20 \%$, the firm's payout rate $\delta_{V}=7 \%$, the drift term of the service flow process $\mu_{S}=6 \%$, the depreciation rate for the service flow $q=5 \%$, the initial service flow $S_{0}=1$, the risk aversion $\delta=0.83$, the recovery rate $\rho_{R}=0.62$, and the level that accounting depreciation is scaled to economic depreciation $\chi=0.5$. Numbers in italics indicate the term structure implied by the endogenous default model.

\begin{tabular}{|c|c|c|c|c|c|c|c|}
\hline \multicolumn{4}{|c|}{$T_{L}=5$ years } & \multicolumn{4}{|c|}{$T_{L}=20$ years } \\
\hline $\begin{array}{c}\text { Default } \\
\text { Boundary } \\
\end{array}$ & $\begin{array}{c}\text { Default } \\
\text { Probability } \\
\end{array}$ & $D / V$ & $\begin{array}{c}\text { Lease } \\
\text { Rate } \\
\end{array}$ & $\begin{array}{c}\text { Default } \\
\text { Boundary } \\
\end{array}$ & $\begin{array}{c}\text { Default } \\
\text { Probability } \\
\end{array}$ & $D / V$ & $\begin{array}{c}\text { Lease } \\
\text { Rate } \\
\end{array}$ \\
\hline \multicolumn{8}{|c|}{ Panel A. $T_{D}=5$ years } \\
\hline 20.00 & $7.65 \%$ & $33.63 \%$ & 1.03 & 20.00 & $7.65 \%$ & $35.05 \%$ & 1.13 \\
\hline 35.14 & $18.82 \%$ & $34.97 \%$ & 1.03 & 30.00 & $14.61 \%$ & $36.70 \%$ & 1.19 \\
\hline 40.00 & $23.14 \%$ & $35.55 \%$ & 1.04 & 34.84 & $18.56 \%$ & $37.83 \%$ & 1.23 \\
\hline 45.00 & $27.93 \%$ & $36.24 \%$ & 1.05 & 40.00 & $23.14 \%$ & $39.33 \%$ & 1.28 \\
\hline 50.00 & $33.05 \%$ & $37.04 \%$ & 1.07 & 45.00 & $27.93 \%$ & $41.09 \%$ & 1.35 \\
\hline 55.00 & $38.48 \%$ & $38.00 \%$ & 1.10 & 50.00 & $33.05 \%$ & $43.26 \%$ & 1.43 \\
\hline 60.00 & $44.22 \%$ & $39.22 \%$ & 1.15 & 55.00 & $38.48 \%$ & $45.96 \%$ & 1.54 \\
\hline 65.00 & $50.25 \%$ & $40.82 \%$ & 1.22 & 60.00 & $44.22 \%$ & $49.43 \%$ & 1.68 \\
\hline \multicolumn{8}{|c|}{ Panel B. $T_{D}=20$ years } \\
\hline 20.00 & $7.65 \%$ & $51.82 \%$ & 1.03 & 20.00 & $7.65 \%$ & $48.14 \%$ & 1.13 \\
\hline 40.00 & $23.14 \%$ & $51.44 \%$ & 1.04 & 30.00 & $14.61 \%$ & $48.21 \%$ & 1.19 \\
\hline 42.08 & $25.09 \%$ & $51.38 \%$ & 1.04 & 40.00 & $23.14 \%$ & $48.24 \%$ & 1.28 \\
\hline 45.00 & $27.93 \%$ & $51.31 \%$ & 1.05 & 40.64 & $23.73 \%$ & $48.24 \%$ & 1.29 \\
\hline 50.00 & $33.05 \%$ & $51.24 \%$ & 1.07 & 45.00 & $27.93 \%$ & $48.32 \%$ & 1.35 \\
\hline 55.00 & $38.48 \%$ & $51.27 \%$ & 1.10 & 50.00 & $33.05 \%$ & $48.51 \%$ & 1.43 \\
\hline 60.00 & $44.22 \%$ & $51.47 \%$ & 1.15 & 55.00 & $38.48 \%$ & $48.86 \%$ & 1.54 \\
\hline 65.00 & $50.25 \%$ & $51.86 \%$ & 1.22 & 60.00 & $44.22 \%$ & $49.43 \%$ & 1.68 \\
\hline
\end{tabular}

TABLE 6

\section{The Impact of Tax Policies on the Lease Rate Term Structure}

Table 6 displays the lease rate term structure for lease maturities $\left(T_{L}\right)$ ranging from 2.5 to 20 years assuming the risk-free interest rate $r=7.5 \%$, the bankruptcy costs $\alpha=50 \%$, the lessor's corporate tax rate $\operatorname{TAX}_{c}=35 \%$, the lessee's corporate tax rate $t_{C}=35 \%$, the firm's asset volatility $\sigma_{v}=20 \%$, the firm's payout rate $\delta_{V}=7 \%$, the drift term of the service flow process $\mu_{S}=6 \%$, the depreciation rate for the service flow $q=5 \%$, the initial service flow $S_{0}=1$, the risk aversion $\delta=0.83$, and the recovery rate $\rho_{R}=0.62$.

Lessor's Tax Rate

Lessee's Tax Rate

Panel A. $\chi=0.5$

$10 \%$

$30 \%$

$50 \%$

$70 \%$

Panel B. $\chi=1.0$

$10 \%$

$30 \%$

$50 \%$

$70 \%$

Panel C. $\chi=1.5$

$10 \%$

$30 \%$

$50 \%$

$70 \%$

\begin{tabular}{llll}
\multicolumn{3}{c}{ Lessor's Tax Rate } \\
\hline $10 \%$ & $\underline{30 \%}$ & $\underline{5} \%$ & $\underline{70 \%}$ \\
& & & \\
1.08 & 1.06 & 1.04 & 1.02 \\
1.11 & 1.08 & 1.06 & 1.04 \\
1.49 & 1.44 & 1.43 & 1.40 \\
1.43 & 1.40 & 1.21 & 1.35 \\
& & & \\
1.07 & & & 0.95 \\
1.09 & 1.03 & 0.99 & 0.96 \\
1.48 & 1.05 & 1.01 & 1.30 \\
1.42 & 1.41 & 1.36 & 1.25 \\
& 1.36 & 1.31 & \\
1.06 & & & 0.87 \\
1.08 & & & 0.89 \\
1.46 & 1.00 & 0.93 & 1.21 \\
1.40 & 1.02 & 0.95 & 1.15
\end{tabular}


accounting purposes by comparing the equilibrium lease rates across Panels A, $\mathrm{B}$, and $\mathrm{C}$ of Table 6 . As expected, the impact of changing the depreciable life is relatively minor when tax rates are low. For example, if lessor and lessee tax rates are $10 \%$, then allowing accelerated depreciation (moving from Panel $\mathrm{A}(\chi<1)$ to Panel $\mathrm{C}(\chi>1))$ results in a $1 \%$ to $2 \%$ decline in the equilibrium lease rate. However, when marginal tax rates are high, the effect of altering the depreciable life becomes material. For example, if marginal tax rates are $70 \%$, then reducing the depreciable life (allowing the lessor to utilize accelerated depreciation) results in a $14 \%$ reduction in the equilibrium lease rate.

\section{Empirical Analysis}

\section{A. Lease Data}

In this section we examine the equilibrium origination lease rates for real estate leases. Using a variety of measures and controls, we are able to test a number of predictions regarding the lease term structure and firm capital structure derived from the theoretical model.

We collect an administrative data set of small business real estate lease contracts financed by a large financial institution. The data set contains detailed information collected from the firms' financial statements, the firms' risk ratings (hard public information) from the national credit bureau (Dunn and Bradstreet), and the financial institution's internal credit score (hard private information) for each business. We also have access to the all-in price of the lease, lease terms (duration, maturity, and amount), firm industrial code, and location of the firm (zip code). The database captures lease originations between January 2001 and March 2002. In total we have access to 2,482 lease contracts underwritten in the $8 \mathrm{New}$ England states, Illinois, and Michigan.

Table 7 reports the descriptive statistics for the sample. The leases contained in the data are to small firms. The average firm has assets of $\$ 4.78$ million and is committing to a lease with an all-in price (present value) of $\$ 423,297$. The average lease has a maturity of 4.98 years. In comparison, the average debt maturity for these firms is 2.47 years. The firms have an average of $\$ 1.46$ million in debt, implying a leverage ratio of $30 \%$. Approximately $40 \%$ of the leases are for office space and $31 \%$ are for retail space.

\section{B. Estimation Results}

Our empirical test of the predictions from the model developed in Section IV follows the spirit of the reduced-form regression framework of Collin-Dufresne, Goldstein, and Martin (2001). The lease equilibrium term structure is reflected in the lease's effective yield to the financial institution. We then calculate the lease pricing spread as the difference between the lease effective yield and the 3 -year constant maturity treasury yield at the date of origination. We estimate the following regression equation:

$$
r^{*}-r_{\text {TREAS }}=X^{\prime} \beta+\varepsilon,
$$




\section{TABLE 7}

Summary Statistics of the Leasing Data

Table 7 reports the descriptive statistics for the administrative data set of real estate lease contracts originated from a large financial institution between January 2001 and March 2002. The data set covers 2,482 lease contracts underwritten in the 8 New England states, Illinois, and Michigan. Lease amount is the present value of the lease contract. External credit score refers to the firm's risk rating (hard public information) obtained from the national credit bureau (Dunn and Bradstreet). Internal risk rating is the bank's proprietary credit score based on hard private information about the firm.

\begin{tabular}{lcc}
\multicolumn{1}{c}{ Summary Statistics } & Means & Std. Dev. \\
Lease amount & $\$ 423,297.30$ & $\$ 447,782.90$ \\
Lease contract maturity (years) & 4.98 & 4.19 \\
Debt maturity (years) & 2.47 & 2.18 \\
Firm size (assets) & $\$ 4,784,322$ & $\$ 3,915,630$ \\
Debt & $\$ 1,458,751$ & $\$ 1,201,745$ \\
Internal risk rating & 3.9385 & 1.5082 \\
External credit score & 717.18 & 81.91 \\
Property type office space & $39.71 \%$ & $13.36 \%$ \\
Property type agriculture land & $31.35 \%$ & $15.58 \%$ \\
Property type retail space & & \\
Property type others & &
\end{tabular}

where $r^{*}-r_{\text {TREAS }}$ is the lease pricing spread, and $X$ represents the set of lease and firm characteristics including: the present value of the lease contract discounted at the bank's cost of capital $\left(L_{R}\right)$, the lease maturity $\left(t_{L}\right)$, the firm's debt maturity at lease origination $\left(t_{D}\right)$, the firm's asset size at lease origination $(V)$, the firm's asset volatility measured as the standard deviation in asset values over the previous 3 years $\left(\sigma_{V}\right)$, the firm's debt-asset ratio at lease origination $(D / V)$, the volatility in the debt-asset ratio measured as the standard deviation in the debt-asset ratio over the previous 3 years $\left(\sigma_{D / V}\right)$, and a set of control variables reflecting the property type being leased (office, agricultural, retail, or other) and the firm's risk rating. We also include zip code fixed effects to control for location-specific factors, month fixed effects to control for temporal difference in the economic environment over the sample period, and Standard Industrial Classification (SIC) fixed effects to control for differences in the firm's industry segment.

Table 8 reports the results for the ordinary least squares (OLS) regression of equation (18). The model has a high degree of fit, as reflected in the $R^{2}$, indicating that the model is able to explain approximately $63 \%$ of the cross-sectional variation in lease rates.

Turning to the individual coefficients of interest based on our theoretical lease term structure model, we first note that the estimated coefficient for lease contract maturity is positive and significant (at the $1 \%$ level), confirming the prediction of a positive relation between lease maturity and the lease spread (Section VI.C). We also see that the estimated coefficient for debt maturity is also positive and significant (at the 1\% level), indicating that firms with longer-term debt face higher leasing costs. Furthermore, the dummy variable indicating that the firm utilizes long-term debt (greater than or equal to 5 years) is also positive and significant at the $1 \%$ level. Thus, the estimated coefficients for debt maturity confirm the prediction in Section VI.D of a positive relation between lease rates and debt maturity.

In Section VI.G, we noted that our lease term structure predicts a positive relation between the firm's asset volatility and the lease rate, which is consistent with the traditional credit risk models. The estimated coefficient for asset 
TABLE 8

Empirical Analysis of Lease Term Structure

\begin{tabular}{|c|c|c|c|}
\hline Variable & $\begin{array}{l}\text { Coeff. } \\
\text { Value }\end{array}$ & $\begin{array}{l}\text { Std. } \\
\text { Err. }\end{array}$ & $t$-Stat. \\
\hline Intercept & 8.1822 & 1.9272 & $4.25^{\star \star \star}$ \\
\hline $\log ($ lease amount) & -1.4934 & 0.2273 & $-6.57^{* * *}$ \\
\hline Lease contract maturity (years) & 0.3704 & 0.0413 & $8.97^{\star * *}$ \\
\hline Debt maturity (years) & 0.3586 & 0.1571 & $2.29^{* *}$ \\
\hline $\log ($ firm size (assets)) & -1.6450 & 0.4011 & $-4.10^{* * \star}$ \\
\hline Asset volatility (std. dev. over 3 years) & 0.5997 & 0.1830 & $3.28^{\star * *}$ \\
\hline $\log ($ debt/assets) & 2.3428 & 0.5117 & $4.58^{* * \star}$ \\
\hline Debt/asset volatility (std. dev. over 3 years) & -0.2038 & 0.1299 & $-1.57^{\star}$ \\
\hline Long-term debt $=1$ & 0.2721 & 0.0391 & $6.96^{\star * *}$ \\
\hline Property type office space & -0.1172 & 0.0232 & $-5.04^{* * *}$ \\
\hline Property type agriculture land & 0.3737 & 0.0377 & $9.88^{* * *}$ \\
\hline Property type retail space & 0.3548 & 0.0389 & $9.12^{* * *}$ \\
\hline Internal risk rating & 0.9782 & 0.1883 & $5.19^{* * *}$ \\
\hline log(external credit score (D\&B)) & -1.0821 & 0.3798 & $-2.85^{\star \star}$ \\
\hline Zip code fixed effects & Yes & & \\
\hline Month fixed effects & Yes & & \\
\hline SIC fixed effects & Yes & & \\
\hline $\begin{array}{l}\text { No. of obs. } \\
R^{2}\end{array}$ & $\begin{array}{l}2,482 \\
0.6291\end{array}$ & & \\
\hline
\end{tabular}

volatility reported in Table 8 is positive and significant at the $1 \%$ level, confirming the model's prediction.

Consistent with the debt/lease trade-off arguments in financial theory (Section VI.B), the regression results indicate a positive and significant (at the $1 \%$ level) relation between the use of debt (leverage ratio) and the lease rate. In other words, as the firm's leverage (debt/asset) level increases, the cost of leasing increases. Thus, this result empirically verifies the trade-off between debt and leases.

Turning to the firm risk ratings, we see that the coefficients for the internal and external risk credit scores are significant (at the 1\% level) and have the appropriate sign. First, the coefficient for the bank's internal risk rating measure is positive, indicating that firms with higher risk factors (as measured by the bank) face higher lease rates. Second, the negative coefficient for the external credit score (higher scores correspond to lower risk) again implies that lower risk firms face lower lease rates.

Finally, we note that the property type control variables are highly significant and consistent with expectation regarding the asset risk. For example, we note that the estimated coefficient for office properties is negative and significant (at the $1 \%$ level), consistent with prior expectations that office space should have higher recovery rates (i.e., be easier to re-lease in case of default) than specialized property types contained in the "other" category. In addition, we see that retail and agricultural properties command a lease rate premium that is consistent with the lower expected recovery rates on these property types. For example, tenants 
in retail spaces are most likely to default during economic downturns affecting all users of retail space.

As a robustness check, we also estimate equation (18) separately for each property type (office, agricultural, retail, and other) in order to verify that the results identified above are not simply a function of differences in contracts across the various property types. Table 9 reports the estimated coefficients from these regressions. We note that all the coefficients are statistically significant and have the same signs as the coefficients reported in Table 8. Thus, the separate regressions again confirm the theoretical predictions of our model. We also note that the magnitude of the estimated coefficients differs across property types reflecting the idiosyncratic property types. For example, the coefficient for debt maturity in the "other" property type is roughly half the magnitude of the "office" property type coefficient. Furthermore, we note that the adjusted $R^{2} \mathrm{~s}$ indicate that the "agricultural" and "other" property type models have approximately half the explanatory power of the "office" and "retail" models. However, the lower explanatory power is to be expected given the greater heterogeneity of uses, and thus risk, associated with agricultural and generic property types.

TABLE 9

\section{Empirical Analysis of Lease Term Structure by Property Type}

\begin{tabular}{|c|c|c|c|c|}
\hline Variable & Office & Agriculture & Retail & Other \\
\hline Intercept & $\begin{array}{l}6.9214^{\star \star *} \\
(2.59)\end{array}$ & $\begin{array}{l}4.7522^{* * *} \\
(1.46)\end{array}$ & $\begin{array}{l}5.3689^{\star \star \star} \\
(1.55)\end{array}$ & $\begin{array}{l}7.1273^{\star \star \star} \\
(3.34)\end{array}$ \\
\hline $\log ($ lease debt amount) & $\begin{array}{l}-1.6713^{\star \star *} \\
(0.44)\end{array}$ & $\begin{array}{l}-1.1308^{* *} \\
(0.60)\end{array}$ & $\begin{array}{l}-1.6276^{* \star *} \\
(0.54)\end{array}$ & $\begin{array}{l}-1.1828^{* *} \\
(0.62)\end{array}$ \\
\hline Lease contract maturity (years) & 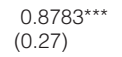 & $\begin{array}{l}0.4370^{\star *} \\
(0.22)\end{array}$ & $\begin{array}{l}0.6028^{* * *} \\
(0.25)\end{array}$ & $\begin{array}{l}0.2095^{\text {*** }} \\
(0.09)\end{array}$ \\
\hline Debt maturity (years) & $\begin{array}{l}0.8499^{* \star *} \\
(0.26)\end{array}$ & $\begin{array}{l}0.5970^{* *} \\
(0.31)\end{array}$ & $\begin{array}{l}0.7664^{* * *} \\
(0.24)\end{array}$ & $\begin{array}{l}0.4310^{\text {*** }} \\
(0.17)\end{array}$ \\
\hline $\log ($ firm size (assets)) & $\begin{array}{l}-2.2271^{\star \star \star} \\
(0.19)\end{array}$ & $\begin{array}{l}-1.4154^{* * *} \\
(0.64)\end{array}$ & $\begin{array}{l}-2.5936^{* * *} \\
(0.53)\end{array}$ & $\begin{array}{l}-3.1919^{\text {*** }} \\
(0.50)\end{array}$ \\
\hline $\begin{array}{l}\text { Asset volatility } \\
\text { (std. dev. over } 3 \text { years) }\end{array}$ & $\begin{array}{l}0.4654^{\star \star *} \\
(0.11)\end{array}$ & $\begin{array}{l}0.3974^{* \star *} \\
(0.13)\end{array}$ & $\begin{array}{l}0.2020^{\star \star *} \\
(0.05)\end{array}$ & $\begin{array}{l}0.3745^{\star \star \star} \\
(0.07)\end{array}$ \\
\hline $\log ($ debt/assets) & $\begin{array}{l}1.3825^{\star \star \star} \\
(0.49)\end{array}$ & $\begin{array}{l}1.2144^{* * *} \\
(0.47)\end{array}$ & $\begin{array}{l}2.0924^{* * *} \\
(0.59)\end{array}$ & $\begin{array}{l}3.1505^{\star \star \star} \\
(0.49)\end{array}$ \\
\hline $\begin{array}{l}\text { Debt/asset volatility } \\
\text { (std. dev. over } 3 \text { years) }\end{array}$ & $\begin{array}{l}-0.3800^{* *} \\
(0.19)\end{array}$ & $\begin{array}{l}-0.3361^{*} \\
(0.23)\end{array}$ & $\begin{array}{l}-0.3938^{*} \\
(0.24)\end{array}$ & $\begin{array}{l}-0.1289^{\star \star \star} \\
(0.05)\end{array}$ \\
\hline Long-term debt $=1$ & $\begin{array}{l}0.1627^{* * *} \\
(0.04)\end{array}$ & $\begin{array}{l}0.4862^{* \star *} \\
(0.07)\end{array}$ & $\begin{array}{l}0.3710^{* * *} \\
(0.10)\end{array}$ & $\begin{array}{l}0.4823^{\star \star \star} \\
(0.07)\end{array}$ \\
\hline Internal risk rating & $\begin{array}{l}0.7195^{\star \star \star} \\
(0.16)\end{array}$ & $\begin{array}{l}0.5216^{* * *} \\
(0.18)\end{array}$ & $\begin{array}{l}0.9341^{\text {*** }} \\
(0.27)\end{array}$ & 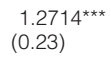 \\
\hline $\log ($ external credit score (D\&B)) & $\begin{array}{l}-1.2570^{\star \star \star} \\
(0.58)\end{array}$ & 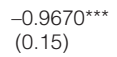 & $\begin{array}{l}-0.8269^{* *} \\
(0.46)\end{array}$ & $\begin{array}{l}-1.3652^{* *} \\
(0.71)\end{array}$ \\
\hline $\begin{array}{l}\text { Zip code fixed effects } \\
\text { Month fixed effects } \\
\text { SIC fixed effects }\end{array}$ & $\begin{array}{l}\text { Yes } \\
\text { Yes } \\
\text { Yes }\end{array}$ & $\begin{array}{l}\text { Yes } \\
\text { Yes } \\
\text { Yes }\end{array}$ & $\begin{array}{l}\text { Yes } \\
\text { Yes } \\
\text { Yes }\end{array}$ & $\begin{array}{l}\text { Yes } \\
\text { Yes } \\
\text { Yes }\end{array}$ \\
\hline $\begin{array}{l}\text { No. of obs. } \\
R^{2}\end{array}$ & $\begin{array}{c}986 \\
0.5918\end{array}$ & $\begin{array}{c}331 \\
0.2012\end{array}$ & $\begin{array}{c}778 \\
0.4991\end{array}$ & $\begin{array}{c}387 \\
0.1827\end{array}$ \\
\hline
\end{tabular}




\section{Conclusion}

The lease rate term structure model has been widely discussed in literature due to its similarity with interest rate term structure. This paper focuses on defaultable lease rate term structure with the application of endogenous default model. This credit risk issue is not new in fixed-income pricing. However, only a few papers (e.g., Grenadier (1996), Clapham and Gunnelin (2003), and Ambrose and Yildirim (2008)) formally model this issue in terms of a lease contract. This paper applies the competitive lease market argument and endogenous default structural model proposed by Leland and Toft (1996) to examine the interaction between a lessee firm's financial decision and lease market; thus, the lease rate determination problem becomes a simultaneous equation problem in contrast with previous studies, which assume the lessee firm's default risk is independent from the lease market.

We examine the lease rate term structure under different scenarios. The results are consistent with previous models except that the recovery rate may not play a significant role in lease rate determination because the impact of the exogenous recovery rate can be offset by the lessee firm's endogenous financial decisions. Further, we examine the interaction between the debt's maturity and lease rate term structure. Shorter debt maturity leads to less cash outflows and reduces the financial burden of debt, thus decreasing the lessee firm's default risk and resulting in a smaller lease rate term structure.

These results provide testable hypotheses about lease rate determination. They include a negative relationship between market price of risk and lease rate, a negative relationship between service flow volatility and lease rate, a negative relationship between lessee's tax rate and lease rate, a positive relationship between lessee's asset volatility and lease rate, and a positive relationship between maturity of existing debt and lease rate. Our empirical analysis of 2,482 small business leases for commercial property confirm these predictions. Overall, our empirical model is able to explain approximately $63 \%$ of the cross-sectional variation in lease rates.

\section{Appendix. Derivations}

1. Derivation of Equation (4)

The closed-form solution for stochastic differential equation (1) can be represented as

$$
S_{\mathrm{BD}}(t)=S_{0} e^{\left(\mu_{S}-\frac{1}{2} \sigma_{S}^{2}\right) t+\sigma_{S} W_{S}(t)}
$$

where $S_{0}$ is the initial service flow of the leased asset, and $W(t)$ is the standard Brownian motion at time $t$ under the true measure. Because the leased asset may not be very liquid or easily traded, in order to obtain the expected present value of the discounted service flow, we employ the market price risk adjustment to derive the service flow process under the risk-neutral measure:

$$
S_{\mathrm{BD}}(t)=S_{0} e^{\left(\mu_{S}-\delta \sigma_{S}-\frac{1}{2} \sigma_{S}^{2}\right) t+\sigma_{S} \widetilde{W}_{S}(t)}
$$


where $\delta$ is the market price of risk for service flow, and $\widetilde{W}(t)$ is the standard Brownian motion under the risk-neutral measure. Using equation (A-1), the present value of the future service flows is

$$
\begin{aligned}
\widetilde{\mathrm{E}}\left(\int_{0}^{t} S_{\mathrm{BD}}(u) e^{-r u} d u\right) & =\widetilde{\mathrm{E}}\left(\int_{0}^{t} S_{0} e^{\left(\mu_{S}-\delta \sigma_{S}-\frac{1}{2} \sigma_{S}^{2}\right) u+\sigma_{S} \widetilde{W}_{S}(u)} e^{-r u} d u\right) \\
& =S_{0} \widetilde{\mathrm{E}}\left(\int_{0}^{t} e^{\left(\mu_{S}-\delta \sigma_{S}-\frac{1}{2} \sigma_{S}^{2}\right) u+\sigma_{S} \widetilde{W}_{S}(u)} e^{-r u} d u\right)
\end{aligned}
$$

Furthermore, by applying Fubini's theorem (refer to Arnold (1974)),

$$
\begin{aligned}
\widetilde{\mathrm{E}}\left(\int_{0}^{t} e^{\left(\mu_{S}-\delta \sigma_{S}-\frac{1}{2} \sigma_{S}^{2}\right) u+\sigma_{S} \widetilde{W}_{S}(u)} e^{-r u} d u\right) \\
=\int_{\Omega} \int_{0}^{t} e^{\left(\mu_{S}-\delta \sigma_{S}-\frac{1}{2} \sigma_{S}^{2}\right) u+\sigma_{S} \widetilde{W}_{S}(u)} e^{-r u} d u d \widetilde{P} \\
=\int_{0}^{t} e^{\left(\mu_{S}-\delta \sigma_{S}-\frac{1}{2} \sigma_{S}^{2}-r\right) u}\left(\int_{\Omega} e^{\sigma_{S} \widetilde{W}_{S}(u)} d \widetilde{P}\right) d u \\
=\int_{0}^{t} e^{\left(\mu_{S}-\delta \sigma_{S}-\frac{1}{2} \sigma_{S}^{2}-r\right) u} \widetilde{\mathrm{E}}\left(e^{\sigma_{S} \widetilde{W}_{S}(u)}\right) d u,
\end{aligned}
$$

where $\Omega$ is the sample space of the random variable $\widetilde{W}(u)$, and $\widetilde{\mathrm{E}}\left(e^{\sigma_{S} \widetilde{W}_{S}(u)}\right)$ is the momentgenerating function of the Brownian motion $\widetilde{W}_{S}(u)$, which is equal to $e^{\frac{u}{2} \sigma_{S}^{2}}$. Therefore, the expected present value of the service flow from 0 to $t$ can be written as

$$
\begin{gathered}
\widetilde{\mathrm{E}}\left(\int_{0}^{t} S_{\mathrm{BD}}(u) e^{-r u} d u\right)=\frac{S(0)}{\left(\mu_{S}-\delta \sigma_{S}-r\right)}\left(e^{\left(\mu_{S}-\delta \sigma_{S}-r\right) t}-1\right), \\
\text { if } \quad\left(\mu_{S}-\delta \sigma_{S}-r\right) \neq 0 .
\end{gathered}
$$

By applying the same technique to the after-depreciation case, we can obtain a similar result:

$$
\begin{gathered}
\widetilde{\mathrm{E}}\left(\int_{0}^{t} S_{\mathrm{AD}}(u) e^{-r u} d u\right)=\frac{S(0)}{\left(\mu_{S}-\delta \sigma_{S}-q-r\right)}\left(e^{\left(\mu_{S}-\delta \sigma_{S}-q-r\right) t}-1\right), \\
\text { if }\left(\mu_{S}-\delta \sigma_{S}-q-r\right) \neq 0 .
\end{gathered}
$$

Inserting equations (A-2) and (A-3) into equation (3) in Section III.A and equating to $r_{N}^{t}\left(\left(1-e^{-r t}\right) / r\right)$, we obtain the expression for $r_{N}^{t}$ in equation (4).

2. Definitions of $G(t), F(t)$, and Relevant Equations

$$
\begin{aligned}
G(t) & =\int_{0}^{t} e^{-r \tau} f\left(\tau ; V, V_{B}\right) d \tau, \\
F(t) & =\int_{0}^{t} f\left(\tau ; V, V_{B}\right) d \tau,
\end{aligned}
$$

and by Leland and Toft (1996), we can represent $G(t), F(t)$ as

$$
\begin{aligned}
F\left(t, V, V_{B}\right) & =N\left(h_{1}(t)\right)+\left(\frac{V}{V_{B}}\right)^{-2 a} N\left(h_{2}(t)\right) \\
G\left(t, V, V_{B}\right) & =\left(\frac{V}{V_{B}}\right)^{-a+z} N\left(q_{1}(t)\right)+\left(\frac{V}{V_{B}}\right)^{-a-z} N\left(q_{2}(t)\right) .
\end{aligned}
$$


Here, $N(\cdot)$ is the cumulative standard normal distribution, and

$$
\begin{aligned}
q_{1}(t) & =\frac{-b-z \sigma^{2} t}{\sigma \sqrt{t}}, \quad q_{2}(t)=\frac{-b+z \sigma^{2} t}{\sigma \sqrt{t}} ; \\
h_{1}(t) & =\frac{-b-a \sigma^{2} t}{\sigma \sqrt{t}}, \quad h_{2}(t)=\frac{-b+a \sigma^{2} t}{\sigma \sqrt{t}} ; \\
a & =\frac{r-\delta-\left(\frac{\sigma^{2}}{2}\right)}{\sigma^{2}}, \quad b=\ln \left(\frac{V}{V_{B}}\right), \quad z=\frac{\left(\left(a \sigma^{2}\right)^{2}+2 r \sigma^{2}\right)^{0.5}}{\sigma^{2}} .
\end{aligned}
$$

\section{Derivation of Equation (6)}

The default-risky lease contract value can be represented as equation (5) in Section III.B. Since $R_{R}^{t-\tau}$ is equal to $r_{R}^{t}\left(\left(1-e^{-r(t-\tau)}\right) / r\right)$, we can further reduce equation (6) in Section III.B to be equation (8) in Section IV.A. In equilibrium, the default-risky lease contract value is equal to the default risk-free lease contract value, which is $r_{N}^{t}\left(\left(1-e^{-r t}\right) / r\right)$. By equalizing equation (8) and $r_{N}^{t}\left(\left(1-e^{-r t}\right) / r\right.$, we obtain the relation between the default risk-free lease rate and the default-risky lease rate in equation (6).

\section{Definitions of $I(t), J(t)$, and Relevant Equations}

$$
I(T)=\frac{1}{T} \int_{0}^{T} e^{-r t} F(t) d t, \quad J(T)=\frac{1}{T} \int_{0}^{T} G(t) d t .
$$

Leland and Toft (1996) show that $I(t), J(t)$ also can be represented as

$$
\begin{aligned}
I(T) & =\frac{1}{r T}\left(G(T)-e^{-r T} F(T)\right) \\
J(T) & =\frac{1}{z \sigma_{V} \sqrt{T}}\left(-\left(\frac{V}{V_{B}}\right)^{-a+z} N\left(q_{1}(T)\right) q_{1}(T)+\left(\frac{V}{V_{B}}\right)^{-a-z} N\left(q_{2}(T)\right) q_{2}(T)\right) .
\end{aligned}
$$

It is important to note that the value of $J(T)$ is greater than the value of $I(T)$; we can observe that from the definition of these 2 functions.

5. Definitions of $K_{1}^{T}, K_{2}^{T}, K_{3}, K_{4}$, and $M$

$$
\begin{aligned}
K_{1}^{T}= & \frac{1}{r T}\left[(-a+z) N\left(-z \sigma_{V} \sqrt{T}\right)+\frac{n\left(-z \sigma_{V} \sqrt{T}\right)}{\sigma_{V} \sqrt{T}}\right. \\
& \left.+(-a-z) N\left(z \sigma_{V} \sqrt{T}\right)+\frac{n\left(z \sigma_{V} \sqrt{T}\right)}{\sigma \sqrt{T}}\right] \\
& -\frac{e^{-r t}}{r T}\left[\frac{n\left(-a \sigma_{V} \sqrt{T}\right)}{\sigma_{V} \sqrt{T}}-2 a N\left(a \sigma_{V} \sqrt{T}\right)-\frac{n\left(z \sigma_{V} \sqrt{T}\right)}{\sigma_{V} \sqrt{T}}\right], \\
K_{2}^{T}=\quad & -a+z) N\left(-z \sigma_{V} \sqrt{T}\right)-\frac{n\left(-z \sigma_{V} \sqrt{T}\right)}{\sigma_{V} \sqrt{T}} \\
& +N\left(-z \sigma_{V} \sqrt{T}\right) \frac{1}{z \sigma_{V}^{2} T}+(-a-z) N\left(z \sigma_{V} \sqrt{T}\right) \\
& -n\left(z \sigma_{V} \sqrt{T}\right) \frac{1}{\sigma_{V} \sqrt{T}}-N\left(z \sigma_{V} \sqrt{T}\right) \frac{1}{z \sigma_{V}^{2} T},
\end{aligned}
$$




$$
\begin{aligned}
K_{3} & =\left(C+\Omega_{R}\right)\left(\frac{t_{c}}{r}\right) x, \\
K_{4} & =\left(1-\rho_{R}\right) \Omega_{R}\left[\frac{1-e^{-r \frac{T_{L}}{2}}}{r}\right], \\
M & =\left(\frac{\Omega_{R}}{r} \rho_{R}\right)\left(K_{1}^{T_{L}} \frac{T_{L}}{T_{D}}-K_{2}^{T_{D}}\right)-\left(\frac{\Omega_{R}}{r} \frac{\rho_{R}}{T_{L}}\right)\left(K_{1}^{T_{L}}-K_{2}^{T_{L}}\right),
\end{aligned}
$$

where $N(\cdot)$ is the cumulative standard normal distribution, and $n(\cdot)$ is the probability density function of standard normal distribution. Other variables are defined in the main context of this paper.

\section{Derivation of Comparative Static in Section VI}

In equation (6), we note that

$$
\begin{aligned}
r_{R}^{t} & =r_{N}^{t}\left[\frac{1-e^{-r t}}{\left(1-e^{-r t}\right)-\left(1-\rho_{R}^{t}\right)\left(G(t)-F(t) e^{-r t}\right)}\right] \\
& =r_{N}^{t}\left(1-e^{-r t}\right) \underbrace{\left[\left(1-e^{-r t}\right)-\left(1-\rho_{R}^{t}\right)\left(G(t)-F(t) e^{-r t}\right)\right]^{-1}}_{\oplus} .
\end{aligned}
$$

Therefore,

$$
\begin{aligned}
& {\left[\left(1-e^{-r t}\right)-\left(1-\rho_{R}^{t}\right)\left(G(t)-F(t) e^{-r t}\right)\right]^{-1}>0, \quad \text { and }} \\
& {\left[\left(1-e^{-r t}\right)-\left(1-\rho_{R}^{t}\right)\left(G(t)-F(t) e^{-r t}\right)\right]^{-2}>0 .}
\end{aligned}
$$

Thus, the comparative static of $r_{R}^{t}$ with respect to $\rho_{R}^{t}$ (the recovery rate) is

$$
\begin{aligned}
\frac{\partial r_{R}^{t}}{\partial \rho_{R}^{t}}= & \underbrace{-r_{N}^{t}\left(1-e^{-r t}\right)\left[\left(1-e^{-r t}\right)-\left(1-\rho_{R}^{t}\right)\left(G(t)-F(t) e^{-r t}\right)\right]^{-2}}_{\ominus} \\
& \times[\underbrace{\left(G(t)-F(t) e^{-r t}\right)}_{\oplus}-\underbrace{\left(1-\rho_{R}^{t}\right)\left(\frac{\partial G(t)}{\partial V_{B}}-\frac{\partial F(t)}{\partial V_{B}} e^{-r t}\right)}_{\oplus}\left(\frac{\partial V_{B}}{\partial \rho_{R}^{t}}\right)] .
\end{aligned}
$$

Since

$$
\begin{aligned}
\left(G(t)-F(t) e^{-r t}\right) & =\left(\int_{0}^{t} e^{-r \tau} f\left(\tau ; V, V_{B}\right) d \tau-e^{-r t} \int_{0}^{t} f\left(\tau ; V, V_{B}\right) d \tau\right) \quad \text { and } \\
\frac{\partial f\left(\tau ; V, V_{B}\right)}{\partial V_{B}} & >0
\end{aligned}
$$

the sign of $\partial r_{R}^{t} / \partial \rho_{R}^{t}$ is determined by

$$
\left[\left(G(t)-F(t) e^{-r t}\right)-\left(1-\rho_{R}^{t}\right)\left(\frac{\partial G(t)}{\partial V_{B}}-\frac{\partial F(t)}{\partial V_{B}} e^{-r t}\right)\left(\frac{\partial V_{B}}{\partial \rho_{R}^{t}}\right)\right],
$$

which is determined by $\left(\partial V_{B} / \partial \rho_{R}^{t}\right)$. When $\operatorname{sgn}\left(\partial V_{B} / \partial \rho_{R}^{t}\right)<0$,

$$
\operatorname{sgn}[\underbrace{\left(G(t)-F(t) e^{-r t}\right)}_{\oplus}-\underbrace{\left(1-\rho_{R}^{t}\right)\left(\frac{\partial G(t)}{\partial V_{B}}-\frac{\partial F(t)}{\partial V_{B}} e^{-r t}\right)}_{\oplus}\left(\frac{\partial V_{B}}{\partial \rho_{R}^{t}}\right)]>0 .
$$


When $\operatorname{sgn}\left(\partial V_{B} / \partial \rho_{R}^{t}\right)>0$,

$$
\operatorname{sgn}[\underbrace{\left(G(t)-F(t) e^{-r t}\right)}_{\oplus}-\underbrace{\left(1-\rho_{R}^{t}\right)\left(\frac{\partial G(t)}{\partial V_{B}}-\frac{\partial F(t)}{\partial V_{B}} e^{-r t}\right)}_{\oplus}\left(\frac{\partial V_{B}}{\partial \rho_{R}^{t}}\right)]
$$

is determined by the amount of every item in the brackets.

\section{References}

Ambrose, B. W.; P. H. Hendershott; and M. Kłosek. "Pricing Upward-Only Adjusting Leases.” Journal of Real Estate Finance and Economics, 25 (2002), 33-49.

Ambrose, B. W., and Y. Yildirim. "Credit Risk and the Term Structure of Lease Rates: A Reduced Form Approach.” Journal of Real Estate Finance and Economics, 37 (2008), 281-297.

Arnold, L. Stochastic Differential Equations: Theory and Applications. New York, NY: Wiley Interscience (1974).

Barclay, M. J., and C. W. Smith, Jr. “The Priority Structure of Corporate Liability.” Journal of Finance, 50 (1995), 899-917.

Black, F., and J. C. Cox. "Valuing Corporate Securities: Some Effects of Bond Indenture Provisions." Journal of Finance, 31 (1976), 351-367.

Brennan, M. J., and A. Kraus. "The Equilibrium Term Structure of Lease Rates.” Working Paper, University of British Columbia (1982).

Brennan, M. J., and E. S. Schwartz. "Corporate Income Taxes, Valuation, and the Problem of Optimal Capital Structure.” Journal of Business, 51 (1978), 103-114.

Clapham, E., and $\AA$. Gunnelin. "Rental Expectations and the Term Structure of Lease Rates." Real Estate Economics, 31 (2003), 647-670.

Collin-Dufresne, P.; R. S. Goldstein; and J. S. Martin. "The Determinants of Credit Spread Changes." Journal of Finance, 56 (2001), 2177-2207.

Geiger, D. "Lehman Brothers to Lease 160,000 s/f at 1301 Sixth." Real Estate Weekly (Dec. 28, 2005).

Graham, J. R.; M. L. Lemmon; and J. S. Schallheim. "Debt, Leases, Taxes, and Endogeneity of Corporate Tax Status.” Journal of Finance, 53 (1998), 131-162.

Grenadier, S. R. "Valuation Lease Contracts: A Real-Option Approach." Journal of Financial Economics, 38 (1995), 297-331.

Grenadier, S. R. "Leasing and Credit Risk.” Journal of Financial Economics, 42 (1996), 333-364.

Grenadier, S. R. "An Equilibrium Analysis of Real Estate Leases.” Journal of Business, 78 (2005), 1173-1213.

Lease, R. C.; J. J. McConnell; and J. S. Schallheim. "Realized Returns and the Default and Prepayment Experience of Financial Leasing Contracts." Financial Management, 19 (1990), 11-20.

Leland, H. E. "Corporate Debt Value, Bond Covenants, and Optimal Capital Structure." Journal of Finance, 49 (1994), 1213-1252.

Leland, H. E., and K. B. Toft. "Optimal Capital Structure, Endogenous Bankruptcy, and the Term Structure of Credit Spreads.” Journal of Finance, 51 (1996), 987-1019.

Lewis, C. M., and J. S. Schallheim. "Are Debt and Leases Substitutes?" Journal of Financial and Quantitative Analysis, 27 (1992), 497-511.

McConnell, J. J., and J. S. Schallheim. "Valuation of Asset Leasing Contracts." Journal of Financial Economics, 12 (1983), 237-261.

Merton, R. C. "On the Pricing of Corporate Debt: The Risk Structure of Interest Rates.” Journal of Finance, 29 (1974), 449-470.

Miller, M. H., and C. W. Upton. "Leasing, Buying, and the Cost of Capital Services." Journal of Finance, 31 (1976), 761-786.

Rosen, A., and P. Rooney. "Rethinking Leases: How Bankruptcy Courts Keep Them Alive." Law Journal Newsletters, 65 (2002), No. 2.

Schallheim, J. S. Lease or Buy? Principles for Sound Decision Making. Boston, MA: Harvard Business School Press (1994).

Schallheim, J. S., and J. J. McConnell. "A Model for the Determination of 'Fair' Premiums on Lease Cancellation Insurance Policies.” Journal of Finance, 40 (1985), 1439-1457.

Smith, C. W., Jr., and L. M. Wakeman. "Determinants of Corporate Leasing Policy." Journal of Finance, 40 (1985), 895-908. 
584 Journal of Financial and Quantitative Analysis

Stanton, R., and N. Wallace. "An Empirical Test of a Contingent Claims Lease Valuation Model." Journal of Real Estate Research, 31 (2009), 1-26.

Warner, J. B. "Bankruptcy Costs: Some Evidence.” Journal of Finance, 32 (1977), 337-347.

Yan, A. "Leasing and Debt Financing: Substitutes or Complements?" Journal of Financial and Quantitative Analysis, 41 (2006), 709-731. 